doi:10.29285/actapinteriana.2021.7.33

\title{
Temesvári Pelbárt: A kisebb testvérek rendjéből való öt szent vértanúról
}

\author{
Bobay Orsolya OFS \\ Pasaréti Páduai Szent Antal plébánia, 1026 Budapest, Pasaréti út 137. \\ bobayorsi@gmail.com
}

Bobay O. (2021): Temesvári Pelbárt: A kisebb testvérek rendjéböl való öt szent vértanúról. Pelbartus di Temesvár: Sui cinque santi martiri dell'ordine dei frati minori. Acta Pintériana, 7: 33-67.

\begin{abstract}
Il sermone del frate minore Pelbárt Temesvári il quale tratta il martirio dei cinque protomartiri francescani, è particolarmente importante per l'anniversario ottocentesco della loro morte. Il presente articolo, oltre la traduzione ungherese e la trascrizione filologica offre anche un commentario e l'analisi della fonte principale per quanto riguarda la descrizione storica della loro vicenda. Il testo originale, pubblicato per la prima volta nella prima parte del Cinquecento, esce per la prima volta in edizione digitale, con alcune osservazioni ipotetiche - basate sull'analisi correlata del testo e della sua fonte sullo stato dell'osservanza ungherese nei primi decenni degli anni 1500.
\end{abstract}

\section{Bevezetés}

Az első ferences vértanúk halálának 800. évfordulója, a róluk való megemlékezés indokolja, hogy közzétegyük Temesvári Pelbárt sermóját, illetve annak magyar fordítását, és összevessük a beszédet annak legfontosabb forrásával. A beszéd átírása és a fordítás az 1502-es augsburgi kiadás alapján készült, az Eötvös Loránd Tudományegyetem Régi Magyar Irodalomtudományi Intézete által müködtetett Domus sermonum compilatorium honlap (http://sermones.elte.hu/) adatbázisának felhasználásával.

A 15-16. század egyik legjelentősebb obszerváns ferences prédikátora, Temesvári Pelbárt 1435 körül született, a korabeli névadási gyakorlatból következtetve Temesvárott vagy környékén. Bizonytalan adatot jelent, hogy születési neve Pál, édesapjának neve azonban biztosan László volt. Ö maga a német Willibrordból származó szerzetesi nevének latinos formáját használva Pelbartus de Temeswar formában használta a nevét. 1458-ban a krakkói egyetem hallgatójaként az egyetemi dokumentumokban Pelbartus Ladislai de Temeswar néven szerepel. Ekkor már valószínűleg a rend tagja volt. 1463. december 17-én szerezte meg a borostyánkoszorús (baccalaureus) fokozatot. Ezt követően közel húsz éven keresztül élte szerzetesi életét, amelyben nagy megrázkódtatást jelentett az 1479-1481 között dúló pestisjárvány. Miután felépült a betegségből, felismerte, hogy Máriához intézett imái mentették meg öt a korai haláltól, és hálából kezdte el írni első művét (Stellarium coronae benedictae Mariae virginis) a Szüzanya tiszteletére - a betegség tehát írói munkásságának kezdetét jelentette.

A négy könyvből álló mű, amelynek megírásakor a compilatio során a szerző a korábbi századok gazdag prédikációirodalmára támaszkodhatott, későbbi írásaihoz hasonlóan szintén sermo-mintákat tartalmaz (cf. V. KovÁCs 1982, p. 414). A mü megírásának kezdetén már teológiai előadásokat tartott a budai kolostorban Petrus Lombardus Négyeskönyve alapján. A Stellarium befejezését követő két 
évtized során Pomerium (Gyümölcsöskert) címen a müfaj neves képviselőinek írásaiból újabb latin nyelvü minta-sermo gyüjteményt állított össze (cf. uo. p. 416). Elsőként a téli beszédsorozat (pars hyemalis) készült el 1489-ben. 1494-ben Esztergomba helyezték át, de a munkát itt is folytatta, és 1496ra befejezte a Sermones de tempore c. kötetet (a De sanctis c. kötet elkészültének ideje nem ismert). 1497-ben visszahelyezték Budára, és 1498-ben már itt készült el az utolsó rész, a Quadragesimale.

A kéziratos munkákkal itt ismerkedett meg Heinrich Grau nyomdász, aki mindegyik kötetből magával vitt egy másolatot Hagenauba, és itt adta ki őket 1498-1499 között. A beszédgyüjtemények megjelenését követően Pelbárt egy enciklopédikus munka megírásába fogott, amelynek Petrus Lombardus említett mủve volt a mintája. Az Aureum rosarium theologiae (Az isteni tudománynak aranyos rózsakoszorúja) első három könyvét, amelyeket 1500 és 1503 között írt, később tanítványa, Laskai Osvát egészítette ki. Temesvári Pelbárt 1504. január 22-én halt meg a budai kolostorban. Életmüvének jelentőségét mutatja, hogy középkori beszédirodalmunk háromnegyed része Pelbárt munkáinak fordítása, illetve átdolgozása; mindez kijelöli az erre a beszédre vonatkozó kutatás további irányvonalát.

A beszéd alapját jelentő történeti események 1219-ben és 1220-ban játszódtak. Ekkor Szent Ferenc egyiptomi útjáról hazatérve öt testvért küldött Marokkóba az iszlám hitüek megtérítésére. A testvérek Portugálián keresztül jutottak el Marokkóba, ahol már a kezdet kezdetén sem volt részük jó fogadtatásban, a konfliktus pedig odáig fokozódott, hogy az uralkodó személyesen végezte ki őket. A coimbrai Szent Jakab-kolostorban helyezték őket végső nyugalomra. Ez az esemény késztette arra Fernando de Bulhões ágostonos kanonokot, hogy az Antal nevet felvéve a ferences rendbe lépjen.

\section{A Pelbárt-sermo fordítása}

Mert őket valóban a vértanúság koszorújával koronázták meg; valóban a boldogságos Ferenc rendjének kisebb testvérei voltak, és ebből kifolyólag tökéletes szentségü férfiak, akiket méltán lehet a cédrusokhoz hasonlítani. Mert a Királyok 3. könyvéhez írott glosszában a következőket olvashatjuk:

„A cédrus romolhatatlan, kellemes illatú, ragyogó külsejü, a kigyókat nagy erövel elüzö és elpusztító fa, amely illik a tökéletesekhez, akiknek a türelme legyözhetetlen, erényének híre kiváló, a jók számára nagyon kedves a jelenlétük, az igazság ellenségeinek megcáfolásához állandó a tekintélyük."

Ezeket írja a glossza. Ebböl kifolyólag tehát a szentségnek és a tökéletességnek ezek a dicsérendő tulajdonságai a kisebb testvérek rendjéből való öt vértanúban igen fényesen ragyogtak; ezért az ő dicsőségükre sermo formájában közöljük a tételnek ezeket a szavait: hiszen ez a koszorúja a mártír kisebb testvéreknek. Azokkal a címszavakkal fogjuk a három titkot tárgyalni, amelyeket velük kapcsolatban figyelembe ajánlunk.

1. A koszorú viseléséről, ugyanitt a testvérek koszorújáról;

2. A szentség magassága csaknem olyan, mint a cédrus magassága, amely nagyon magas fa;

3. A dicsőség boldogságáról, mikor a Libanon-hegyen levő ültetvénynek nevezik, amelyet ragyogásként értelmeznek, és ezért a legnagyobb dicsőség ragyogását jelenti.

Elsőként álljon itt következtetésként Gergelynek az apostolokról szóló szentbeszédben tett megállapítása a vértanúság koszorújáról, amelyet ezek a szent testvérek bírtak:

„Íme Isten választottai megfékezik testüket, megerösitik lelküket, parancsolnak a démonoknak, erényekkel ékeskednek, a földi dolgokat megvetik, az örök haza felé futnak, és kinszenvedések által jutnak el oda." 
Ebben a dologban a mi lustaságunk megróható, mivel nem akarunk egy kis fáradságot sem elszenvedni a kimondhatatlan dicsőség koszorújáért, hogy férfiasan küzdjünk az ördög ellen és harcoljunk a testi vágyak ellen. Tehát ez a kérdés merül fel: miért van az, hogy most csak nagyon kevesen szenvednek vértanúságot Krisztus Jézusért, és nem is törekednek arra, hogy elérjék az égi koszorú igen jeles jutalmát, bár egykor Isten szentjei és a hívő keresztények mégis kölcsönösen siettek a Krisztusért való büntetést vállalni. Arra, hogy miért történt ez, Órigenésznél és a Számok könyve 18. fejezetéhez írott glosszában találjuk meg a választ - többek között leginkább három okból.

Ad 1. Az első okot a saját részünkről tapasztalhatjuk, mivel annyira langyosak lettünk és az erényekben annyira szegények, hogy nem érdemlünk ilyen nagy kegyelmet, és nem vagyunk méltók arra sem, hogy Krisztusért üldözéseket szenvedjünk. Mert ahogy Gergely is mondja a szüzekről szóló homíliában,

„, a mártír testben nem halhat meg Istenért, ha korábban az elméjében nem halt meg a földi vágyak számára. De mivel lelkünk mélyén még nem haltunk meg a földi vágyaknak, nem vagyunk méltók arra, hogy Krisztusért szenvedjünk."

Itt a belső megtérésről szóló könyv szerzője így ír:

„Ó, ember, bárcsak méltó lennél arra, hogy Jézusért valamennyit szenvedj, ugyanis boldog az, aki szenvedni tudott Krisztusért."

Erről maga a Máté evangéliumának 5. fejezete tanúskodik így szólva:

„Boldogok vagytok, ha énmiattam gyaláznak és üldöznek titeket, és mindenféle rosszat hazudnak rólatok. Örüljetek és ujjongjatok, mert jutalmatok böséges a mennyekben, hiszen így üldözték a prófétákat is, akik elöttetek éltek."

(Mt 5,11-12)

Ad 2. A második ok vagy érv az ellenség részéről áll fenn, mivel az ördög, aki tudja, hogy az emberek a vértanúság által a legnagyobb boldogság koszorúját nyerik el, irigy lévén nem akarja elvenni tôlünk ezt az üldözőt, hogy akadályt támasszon boldogságunk útjába, és ne birtokoljuk azt a végső jót, amit ő elveszített, ezért ír így a Számok könyvéhez írt glossza:

„Nem érdemeljük meg, hogy Krisztusért üldözést szenvedjünk. Mivel ugyanis az ördög tudja, hogy a vértanúság szenvedése miatt bünbocsánatot nyerünk, nem akarja, hogy ez az üldözés meggyötörjön minket, mivel irigykedik dicsöségünkre."

Ez a glossza az Originales vértanúságról szóló fejezetében szerepel, azonban azt, hogy miként vessünk gáncsot ebben az ördögnek, hogy mégse nélkülözzük legalább a lelki vértanúságnak a boldogságát, Gergely tanítja a mártírokról szóló szentbeszédben, a következőket mondva:

„A vértanúságnak két fajtája van, az egyik rejtve az elmében, a másik pedig egyszerre nyilvánul meg az elmében és a cselekvésben. Így tehát vértanúk lehetünk, bár nem gyilkolnak le minket fegyverrel, hiszen míg az üldözö által meghalni nyilvánvaló vértanúság, a jogtalanságok elviselése és a minket gyülölö szeretete rejtett, gondolati vértanúság."

És alább azt írja, ,,nem fegyver általi vértanúk lehetünk, ha igazán örizzük szivünkben a türelmet”. Ezeket (mondja) Gergely, és ugyanezt tanítja Bernát is abban a beszédben, amelynek az első szava „ünnep”, így szólva:

„, tudniillik ugyanazt az igéretet kapták a szegények, mint a mártírok, mivel az Üdvözitö kijelentette, boldogok a lélekben szegények, mivel övék a mennyek országa, és szintén ö mondta, boldogok, akik üldözést szenvednek az igazságért, mivel övék a mennyek országa; íme mindkettônek ugyanazt az országot igérik." 
Ennek az értelmét magyarázza Bernát, amikor azt mondja, hogy az önkéntes szegénység valóban a vértanúság egy fajtája, mert súlyosabb vértanúság, mint lakomán éhezni, sok ruha között megfagyni, a szegénységtől szorongatást szenvedni a gazdagság közepette - ha ezekre fáj a fogunk. Arra, hogy vajon nem méltón koszorúzzák meg azt, aki ily módon törvényesen küzdött, ő azt feleli: ,, tudniillik úgy vetünk gáncsot az ördögnek, hogy valamely módon megszerezzük a vértanúság boldogságát”.

Ad 3. A harmadik ok vagy érv a könyörülő Isten részéről nyilvánul meg, Aki ismerve középszerüségünket és gyengeségünket, megkímél minket jósága miatt, és segítve, irgalmasan leereszkedik, e szerint a zsoltár szerint:

„, Ahogy az apa megkönyörül fiain, úgy könyörül az Úr azokon, akik öt félik. Tudja jól, milyen az alkatunk." (Zsolt 103,13-14)

Hogy mégse nélkülözzük az égi dicsőséget, Isten, mint kegyes atya könnyebbé akarta tenni a vértanúságot annál, amit el tudunk viselni, hogy testünk halálra adását és a bünök kiengesztelését (megtehessük) a valódi bünbánat és a vétkektől való tartózkodás által, hogy legalább ebben alakuljunk az értünk szenvedő Krisztushoz, és elégtételt adjunk neki. Ezért az apostol buzdít minden keresztényt a Zsidóknak írt levél 12. fejezetében:

„Emeljük tekintetünket [...] Jézusra, aki a rá váró öröm helyett elszenvedte a keresztet, nem törödött a gyalázattal, és most Isten trónjának jobbján ül. Igen, gondoljatok örá, aki a bünösök részéröl ekkora ellentmondást viselt el, hogy ne lankadjatok, és bensöleg el ne csüggedjetek. A bün elleni küzdelemben még nem álltatok ellen a véretek ontásáig. " (Zsid 12,3-4)

És a Galatáknak írt levél 5. fejezetében:

„Akik Krisztus Jézushoz tartoznak, keresztre feszitették testüket szenvedélyeikkel és kívánságaikkal együtt. Ha a Lélek szerint élünk, viselkedjünk is a Léleknek megfelelöen." (Gal 5,24-25)

Ennélfogva Gergely is a tömeghez beszélő Jézusról szóló homíliában ezt mondja:

„Bármennyire hiányzik is az alkalom az üldözésre, mégis a békében is lehetséges a vértanúság, ha lelki karddal öljük meg a testi vágyakat."

Szintén Bernát a vértanúság kérdésével kapcsolatban azt írja, hogy

„az a test mindennapi halálra adását jelenti. Hiszen az a vértanúság, amelyben fegyverrel vágják le a végtagokat, kegyetlenebb az irtózatnál; az elöbbi pedig a huzamossága miatt terhesebb számotokra. Ezeket mondja ö, ó, keresztény, hogy magukat a szent vértanúkat tekintsd példának, hogy miért szunyókálsz, miért vagy érzéketlen, hiszen akarva-akaratlan meghalsz, el kell hagynod ezt a világot, és nyomorult testedet a férgeknek adod eledelül. Miért akarod érte és vele a lelkedet elveszejteni? Fegyelmezd testedet, gyakorolj bünbánatot, hogy a vértanúkkal együtt tudj örülni a (mennyei) hazában. Így gondoskodsz jól lelkedröl és testedröl."

Másodszor a szentség kiemelkedő tökéletességéről, amely által ezek a szent vértanúk ragyogtak, ahogy megfigyelhető a cédrussal való összehasonlításban, amely igen magas fa. Cassiodorus ugyanis a 28. zsoltárral kapcsolatban azt írja: „a cédrusok, amelyek máshol nőnek, nem annyira magasak, Libanonban azonban olyanok találhatóak, hogy minden fa magasságát meghaladni látszanak”. Ezeket mondja ö. Ennélfogva fogadjuk el következtetésként, hogy ezeknek a vértanú kisebb testvéreknek a tökéletes szentségére a regulára tett fogadalom és ennek megtartása miatt méltán lehet igen magas cédrusként tekinteni. A regula három szabályából vonható le ez a következtetés: 
Elsőként a szegénység fogadalmából,

Másodszor a tisztaság fogadalmából,

Harmadszor az engedelmesség fogadalmából és ennek erényéből.

Ad 1. Elsőként a szegénységi fogadalomból, mert Haymo az Énekek énekével kapcsolatban ezt mondja: , a cédrus úgymond szépségben, eröben, magasságban, illatban megelözi az erdők minden ékét”.

a. A kisebb testvérek szegénysége így valóban megelőzi más szerzetesek szegénységét, először is az evangéliumi tökéletesség szépsége miatt, ahogy a regula írja: „, A kisebb testvérek regulája és élete ez: kövessék a mi Urunk Jézus Krisztus szent evangéliumát és éljenek engedelmességben, tulajdon nélkül és tisztaságban", és ez itt az utánzás szépsége, és a megfeszített Krisztushoz való hasonlóság szépsége. Ugyanis Ágoston azt mondja, hogy „Krisztus számunkra mindenhol szép, szép a jászolban, és fóként szép a keresztfán”. A megfeszített Krisztus szépsége minden bizonnyal nem azon múlt, hogy egy, két vagy három szög tartotta a kereszten, de három szögön, a kereszten függve nagyon szépnek tünik a kegyes és hívő elme számára. Így a kisebb testvérek regulája ebben a három fogadalomban valóban nagyon szépen utánozza Krisztust, ahogy a Galatáknak írt levél 2. fejezete írja: „Krisztussal együtt keresztre vagyok szegezve: élek én, de már nem én, hanem Krisztus él bennem” (Gal 2,19); és így nyilvánvalóvá válik a szépség.

b. Másodszor, amiként a cédrus nyilvánvalóan kimagaslik erősségben, úgy a kisebb testvérek szegénysége is az élet viszontagságainak erősségét tekintve, mivel ahogy Kelemen pápa mondja, , $a$ szük ösvény felé tartanak", vagyis a szűkölködő szegénység felé.

c. Harmadszor magasságban emelkedik ki a cédrus, így a kisebb (testvérek) szegénysége a legnagyobbnak nevezhető, ahogy a boldogságos Ferenc mondja a regulában:

„A fenséges szegénységnek ez a magassága avatott titeket, kedves testvéreim, a mennyek országának örököseivé és királyaivá, földi kincsekben szegénnyé tett, s erényekben magasra emelt."

d. Negyedszer, ahogy a cédrus nyilvánvalóan kitünik illatát tekintve, úgy a kisebb (testvérek) szegénysége a legszentebb szegénység illatával fog vonzani nagyon sok szent lelket a jámborságra és utánzásra, ahogy az Énekek énekéhez írt kommentár első fejezete mondja:

„Vonj be minket keneteidnek illatával, ifjan fogunk futni, vagyis Krisztusban lángoló lelkekként." (Cf. BERNARDUS 1765, p. 271)

Ad 2. Másodszor a tisztaság fogadalmából nyilvánvaló az előbbi következtetés, mivel ahogy Orosius mondja az Énekek énekéröl írt kommentárban, ,, a cédrus romolhatatlan fa, amely az illatával elüzi a kígyókat és legyeket, és nagyon illatos”. Ezeket mondja ö. Így a szent tisztaság, amelyet ezek a boldog testvérek megfogadtak a regulában, ellentétes a test megromlásával. A testben lévő meleg mozgása elüzi a kígyókat, a testies rossz gondolatok legyeit, és jó illata van Isten és az angyalok előtt. Tudniillik az Énekek énekéhez írt kommentár utolsó fejezete írja, hogy „Krisztus kedves szentje szívesen legel a tisztaság liliomai között” (cf. uo. p. 346).

Ad 3. Harmadszor az engedelmesség fogadalmából, ahogy ugyanis szintén Onorius mondja az Énekek énekéhez írt kommentárjában: 
„A cédrusnak a többi fánál szilárdabb gyantája van, mivel gyógyitja a beteg testrészeket, elpusztítja a kelevényekben levö férgeket, és a férgektöl mentesen fedett marad."

Miként a Sirák fia könyve 24. fejezetéhez írt glossza tanúsítja:

„A cédrusgyantával megkent könyvet sem az elöregedés, sem a szú nem pusztítja el."

Végül pedig Krisztus keresztje főként cédrusból készült, egészen a kereszt függőleges szárának alsó részéig - számolnak be róla a források. Szent Kelemen legszentebb Szentháromságról írt könyvének a kereszt szóhoz írott glosszája pedig találóan jegyzi meg, hogy a kisebb testvérek engedelmessége minden áldozathoz képest kimagasló erény. A Királyok könyve 15. fejezete szerint: „,Többet ér az engedelmesség, mint a véresáldozat" "3 - ugyanis ez lelkileg gyógyítja a bágyadt tagokat, és elpusztítja a kelevényekben élő férgeket, mivel ahogy Hugo írja a szentségekről írt I. könyv 11. paragrafusában: ,ahogyan ugyanis minden bün az engedetlenségböl fakad, úgy minden erény az engedelmességgel kezdödik; szintén ez öriz meg a bünök férgeitöl”, illetve ahogy Szent Ágoston mondja a De civitate Dei 10. könyvében: ,,az engedelmesség minden erény anyja és öre”. Ezenfelül miként Krisztus elszenvedte a kereszthalált az Atya iránti engedelmességből, ahogy a Filippieknek írott levél második fejezete mondja: „Megalázta magát, engedelmes lett a halálig, mégpedig a kereszthalálig” (Fil 2,8),

úgy ezek a boldog testvérek is a szeráfi Ferenc atya iránti engedelmességből indultak el a vértanúság vállalására, ahogy nyilvánvaló lesz majd a legendában.

Felmerül itt a kérdés, hogy ezek a boldog testvérek a vértanúságukban megkapták-e a nagyobb jutalmat az engedelmesség erénye miatt. Ugyanis a szeráfi Bonaventura azt feleli A vallás hatásáról címü müvében, hogy „,minden jó, ami az engedelmességböl fakad, kétszeresen érdemszerzö”. Egyrészt maga a jó tett miatt, az iránta való fáradozásból, az Apostol szava szerint a Korintusiaknak írt első levél 3. fejezetében: „,mindegyikük a saját jutalmát nyeri majd el munkája szerint” (1Kor 3,8). Más módon szereznek érdemet magából az engedelmességből kifolyólag, amely olyan nagy és olyan gazdag erényben, hogy bármely áldozathoz képest előnyben részesítik a Királyok 1 . könyvének 15 . fejezete szerint. Gergely a Jób könyvéhez írt kommentár 7. fejezetében megjegyzi: „tudvalevöleg az engedelmességet joggal helyezik az áldozat elé, mivel az áldozatok által idegen testet, az engedelmesség által pedig a saját akaratot áldozzátok fel”. És ahogy ugyanott érvel, annál inkább érdemszerző az engedelmesség, amikor az engedetlenség a jóslás vétkében nyilvánul meg. Ezenfelül amennyivel kedvesebb és elfogadottabb jóként felajánlani akaratunkat Istennek az engedelmességben, annyival nagyobb érdemet is jelent. Tehát nem kétséges, hogy ezek a szentek a vértanúságban kettős jutalmat érdemeltek ki egészen odáig, hogy a vértanúság dicsőségét és a különleges dicsőséget nyerték el engedelmességből magukat gyötörve.

Harmadszor, a boldogságuk dicsőségével kapcsolatban álljon itt következtetésként, hogy ezeknek a szent testvéreknek a Krisztust utánzó vértanúsága sokszorosan bizonyítva dicsőséges lesz.

Ad 1. Ez elsőként az alázatos engedelmességből nyilvánvaló. Miként ugyanis Krisztus a legalázatosabban engedelmeskedett az Atyaistennek és vállalta a kereszt vértanúságát, így ők igen alázatosan Istennek és a boldog Ferenc atyának engedelmeskedve vállalták a vértanúságot, amely ahogy fentebb mondtuk - a legnagyobb dicsőséget jelenti a számukra. Az Úr 1236. évében, a boldog Ferenc megtérésétől számított 13. évben Isten azzal bízta meg a boldog Ferencet, hogy küldjön néhány testvért a marokkói királyságba a prédikálás és a vértanúság elnyerése céljával. Isten akaratából a boldog Ferenc tehát hat csodálatos szentségü testvért küldött: Vitalis testvért, akit a többiek élére elöljárónak tett meg Beraldus testvért, Ottó testvért, Accursius testvért, Péter testvért és Adiutus testvért. Mikor

3 1Sám 15,22: „, az engedelmesség többet ér, mint az áldozat, a szófogadás értékesebb a kosok hájánál”. 
pedig az aragóniai királyságba érkeztek, Vitalis testvér súlyosan megbetegedett. Látva, hogy betegsége hosszan elnyúlik, és ez a feladatuk elvégzését megakadályozza, ő maga ugyanott maradt, a többiek pedig az engedelmesség teljesítésére továbbhaladtak.

Ad 2. Másodszor, az isteni kinyilatkoztatásból: miként ugyanis Krisztus előre látta és elöre megmondta a halálát, így ők is. Mikor ugyanis a nevezett testvérek Coimbrába értek, az Oracha nevü királynő, mivel látta bennük a világ megvetését és oly nagy szenvedélyt a Krisztusért vállalt halálra, jámboran fogadva állhatatosan kérte őket, hogy imádkozzanak Istenhez, vajon mikor fejeződik be földi élete. Ök azt mondták, hogy méltatlanok az isteni titkok kifürkészésére. Azonban az állhatatos kérések és a királynő könnyei miatt az erős hittel könyörgők számára nem csak az nyilváníttatott ki az isteni jövendölés által, amit kértek, hanem ezenfelül az általuk vállalandó vértanúság is, továbbá az, hogy a testüket oda fogják vinni Marokkóból, és maga a királynő fogja az egész néppel együtt tisztelettel fogadni. Ök tehát mindezeket és a királynő végső napját elöre megmondták, és ilyen módon valósult meg később minden.

Ad 3. Harmadszor, az önkéntes szenvedés miatt bizonyul nagyon dicsőségesnek a vértanúságuk, mivel ahogyan Krisztus önkéntesen vállalta a szenvedést, így ők is isteni kinyilatkoztatás által elöre mondottan vállalták azt, és nehézségek árán jutottak el a szaracénok Sibilia nevü városáig. Végül a tüzes lélekkel mindenfajta vezető nélkül jutottak el a fötemplomukhoz, ahova be akartak lépni, amikor a méltatlankodó szaracénok kiáltozva, lökdösve, ütlegelve támadták meg őket, és egyáltalán nem engedték a belépést. Ugyanis az a szokásuk, hogy egyetlen keresztény vagy egyetlen felekezet sem léphet be templomaikba.

Ad 4. Negyedszer, a hit megvallása és a lángoló szívü prédikálás miatt, mivel ahogy Krisztus szenvedett az evangéliumi hitért, úgy ök is. Miután végül beléptek a palota kapuján és a királyhoz, kijelentették, hogy a királyok királyának, az Úr Jézusnak a követei. Mivel a királynak sok dolgot magyaráztak a katolikus hittel kapcsolatban, és Mohamednek, valamint törvényének kárhozatos hazugságait leleplezték, a haragos uralkodó megparancsolta, hogy fejezzék le őket; de fia szavai hatására lecsillapodott, és megparancsolta, hogy zárják őket egy magas toronyba. Ök azonban a torony magasából Krisztus hitét hirdették mindenkinek, aki elhagyta a királyi udvart, és Mohamed követőit rászedetteknek és örök pusztulásra ítélteknek nevezték. Akkor a király ugyanannak a toronynak az aljába záratta őket, és később az idősek tanácsára (hallgatva) Marokkóba küldte a keresztény Péter úrral és más katolikusokkal együtt, a nevezett Péter úr pedig a meggyötörteket nagy jámborsággal befogadta a szállására és a szükséges dolgokkal ellátta őket. Ezt a Péter urat infánsnak nevezik, mivel Hispániában a királyok fiait az elsőszülöttet követően infánsnak szólítják. A testvérek mindenütt, ahol csak szaracénokat láttak, tüzesen prédikáltak, és mikor Beraldus testvér a piactéren egy szekérre felállva beszélt, Miramolinus király - ott áthaladva azzal a céllal, hogy a királyok sírjait a falakon kívül felkeresse - látta a prédikáló testvért; a fejébe vette, hogy mind az öt testvért úzzék ki a városból, és a keresztények segítségével haladéktalanul küldjék vissza őket a hívők földjére. Akkor Péter infáns úr néhányat vezetőként adott a szolgái közül, és így távozásra kényszerültek.

Ad 5. Ötödször (dicsőséges) a vágyból és az ismételt felajánlásból, mivel ahogyan Krisztus nem egyszer szembenézett ellenségeivel, így ők is, amikor visszavitték őket, vezetőik elbocsátása után ismét visszatértek Marokkóba, és prédikálni kezdtek a piactéren. Ekkor a király börtönbe záratta őket, ahol étel nélkül húsz napig csak az isteni gondviselés vigasztalásában volt részük. Ezután hatalmas meleg lett, és hirtelen időjárásváltozás következett be. Mivel úgy gondolták, hogy ez a megkínzottak bebörtönzése miatt történt, a király az Úr tanácsára szabadon engedte őket a börtönböl és a keresztényekre bízta, hogy késedelem nélkül küldjék vissza őket keresztény területre; ugyanis mindenki csodálkozott, hogy húsz napig étel és ital nélkül sértetlenek maradtak. Amikor pedig a testvéreket a hívők területére vezették, ők az útról letérve visszatértek Marokkóba. Miután tanácskozott a keresztényekkel, ekkor Péter infáns úr a szállásán tartotta őket őrizet alatt, nehogy nyilvánosan 
mutatkozzanak. Később az uralkodó Péter urat a seregével együtt néhány lázadó szaracén ellen küldte, ő pedig magával vitte a szent testvéreket. Történt, hogy három napon keresztül nem tudtak sehol sem maguknak és nekik ivóvizet találni. Mivel ezért kétségbe estek az életükkel kapcsolatban, Beraldus testvér imádságát követően egy kis cöveket vett kézbe, és a földet megütve rögtön forrás fakadt, amelyből az emberek és állatok teleitták magukat és megtöltötték tömlöiket. Rögtön azután, ahogy ezt a jelet megcselekedte, a forrás kiszáradt, hogy világos legyen, hogy csak isteni csoda hozta létre ott a vizet. Ettől a nagy csodától megrendülve mindenki tisztelni kezdte őket és a lábukat csókolták.

Ad 6. Hatodszor, a kegyetlen megölésük miatt dicsőséges a vértanúságuk, ugyanis ahogy Krisztust kegyetlenül ölték meg, úgy őket is, bár egészen más nép tette ezt. Végül is, miután a sereget elhagyva visszatértek Marokkóba, a testvérek a házat titokban elhagyva és Krisztust merészen hirdetve megjelentek Miramolinus király előtt. Ö haragra gyúlva megparancsolta egy bizonyos szaracén hercegnek, hogy fejezze le őket, majd szolgákat küldött oda, akiknek megparancsolta, hogy üssék arcul és verjék meg őket. Akkor a keresztények halálfélelmükben a házaikba menekültek. Amikor (az uralkodó) látta, hogy az odavezetettek állhatatosak a hit megvallásában, különféle kínzásokkal kezdte gyötörni őket. Ekkor erősen megostoroztatta őket, végül összekötött lábakkal a földön ide-oda húzva annyira megverték öket, hogy szinte kilátszottak a belső szerveik. Ezután a sebeikre forró olajat és ecetet öntöttek, és a fejüket is ezzel öntözték. Így gyötörte őket harminc szaracén egész éjszaka. Ugyanazon az éjszakán az őrök látták, hogy nagy fény szállt le az égből, és a szent testvéreket magába fogadva az égbe emelte őket megszámlálhatatlan sokasággal együtt; egyesek a látomáson csodálkozva odamentek a börtönhöz, és hittel imádkozva találták őket. A marokkóiak királya azonban ezeket hallva haragra gyúlt és feltette magában, hogy a színe elé vezetteti a testvéreket. Ekkor levetkőztetve, megkötözve, és folyton ütlegelve a király elé vezették őket, ő pedig azt kérte tőlük: „, Térjetek a mi hitünkre, sok pénzt adok nektek és tisztelni fognak titeket az országomban." Miután bevezettek néhány asszonyt, azt mondta: Öket feleségül adom hozzátok.” A szentek válasza a következő volt: „,Mindent megvetettünk Krisztus miatt, és készek vagyunk a hitért meghalni"; akkor a király, miután kivonta a kardját, az egymástól különválasztott szenteknek a homlokuk közepén egymás után betörte a fejét, és három kardot egymással összefogva a saját kezével, vad kegyetlenséggel lefejezte őket, és így elnyerték a dicsőséges vértanúságot.

Ad 7. Hetedszer, a számos csodájuk megvilágosító hatása miatt, amelyek közül néhányat röviden elmondunk. Amikor ugyanis a testüket a szaracénok tüzben akarták elégetni, a tüz csoda folytán kialudt; hasonlóan, a keresztények közül azok elött, akik a paráználkodás miatt méltatlanok voltak az ereklyéket érinteni, ha nem gyóntak előtte, a (testek) a levegőbe emelkedtek, vagy amazokat hagyta el minden erejük. Végül Péter infáns úr hozzájuk könyörögve elnyerte azt, hogy a király engedélyt adjon neki a Hispániába való visszatérésre, ő pedig magával vitte az ereklyéket, és általuk számos veszélytől megszabadult az úton. A tengeren töltött viharos éjszakán is, veszélyektől félve ezekhez a szentekhez imádkoztak, később pedig Isten ragyogó fénnyel ajándékozta meg őket, és így sértetlenül érkeztek meg Hispániába. Oracha királynő a hír hallatán az egész néppel együtt az ereklyékhez sietett, ünnepélyes tisztelettel a coimbrai Szent Kereszt-kolostorban helyezte el őket, és ahogy a szentek előre megmondták, a királynő az Úrhoz költözött. Az éjszaka ugyanazon órájában egy bizonyos Péter kanonok, sekrestyés és a királynő gyóntatója, a templomban számos, kórusban belépő kisebb testvért látott, akik között volt egy nagyon ünnepélyesen haladó, és utána másik öt, akik kimondhatatlanul dallamosan énekelték a matutinumot. Megrendülve megkérdezte az egyiküktől, honnan jöttek be, amikor a kapu és az ajtók zárva vannak, aki erre azt felelte:

„,kisebb testvérek vagyunk, akik az égben már uralkodnak Krisztussal. Aki elöl megy, boldog Ferenc, a másik öt pedig a vértanú testvérek közül való; és tudd meg, hogy ebben az órában Oracha királynö, aki rendünket nagyon szerette, 


\section{eltávozott. Krisztus Jézus azért küldött bennünket, hogy elvigyük a lelkét az égbe."}

Ezután eltüntek. Nem is kellett más bizonyíték: máris jött a hírnök a királynő eltávozását tudatni. Kérjük Krisztust, hogy az ő érdemeik által adjon nekünk kegyelmet és dicsőséget. Ámen.

\section{Magyarázat}

A vértanúságnak mint a Krisztus-követés radikális vállalásának a korai ferences hagyományban kiemelt szerepe volt, és különös jelentőséggel bírt a 15. század végén kialakulóban lévő ferences obszervancia számára is (cf. BERTAZZO 2011, p. 24). Az 1219 és 1221 közötti eseményekkel kapcsolatban az első tudósítás (1262 körül) Giordano da Gianótól származik, ő azonban nem közli a testvérek nevét, csak a számukat. ${ }^{4}$ A szakirodalom jelenlegi feltételezése szerint létezett egy kortárs beszámoló a vértanúságukról, azonban Ferenc nem engedélyezte ennek használatát. A 14. századtól kezdve az első rendben egyre nagyobb igény merül fel a kanonizált szentek életrajzainak rendszerezésére, martirológiumok összeállítására: ennek az egyik példáját jelenti a Chronica XXIV generalium ordinis minorum (kb. 1470), amely összefoglalja a marokkói vértanúk történetét is, és amelyet Pelbárt is átvett. ${ }^{5}$ Ebben a szövegben már szerepel a testvérek - Berárd, Péter, Ottó, Accursius és Adiutus - neve, valamint Miramolinus alakban az őket kivégző II. Juszuf almohád kalifa (1203-1224) neve. A 15. század végén és a 16. század elején az öt marokkói vértanú vált a legnépszerübbé a korábbi századok ferences vértanúi közül. Ennek a hátterében 1481-es kanonizációjuk állhat, amely keresztény részről az Otranto ostromára adott válasz volt. Az öt vértanú testvérnek volt egyedül kultusza a 19. század előtt kanonizált vértanú ferences első rendiek közül. Képi ábrázolásaikra a szászországi, kamenzi ferences templom oltárképén, a firenzei Santa Croce templom szószékén találunk példákat: itt Páduai Szent Antallal együtt szerepelnek, aki a történetük hatására lépett a kisebb testvérek rendjébe (cf. MACEviTT 2020, p. 190). Az első magyarországi szöveg, amelynek témája a marokkói vértanúk története, Pelbárt jelen tanulmányban közölt beszéde. A beszéd két részre osztható: a Chronica XXIV generalium ordinis minorum szövegére alapozó eseménytörténetet megelőzi a történet teológiai megalapozását célul kitüző szakasz, amelyet a szerző szentírási és patrisztikus forrásokra alapozva épített fel. Múfaji kereteit a skolasztikus sermo müfaja határozza meg, az egyik gyakran alkalmazott forrását pedig az első rend regulája jelenti. További sajátosságként kiemelhető az egész beszéd Krisztusközpontúsága, amelynek a hátterében szintén a ferences lelkiség hatása fedezhető fel.

A sermo modernus módszertanát alkalmazó beszéd a Pomerium sanctorum pars hiemalis szakaszában szerepel, és a festum chori (alkalmi vagy fogadalmi ünnepeken elmondott) beszédek közé tartozik. Ez az egyetlen beszéd ebben a témakörben, amiböl arra következtethetünk, hogy jelentős ünnepet jelentett, a rend(tartomány) saját ünnepét. Egyetlen beszédet ugyanis a kötet abban az esetben

4 A latin nyelvủ kézirat olasz fordításából: „,Dei frati, poi, che passarono per la Spagna, cinque furono coronati del martirio, Se poi questi frati furono mandati da quel Capitolo, cui abbiamo accennato, o da uno precedente, come frate Elia con i suoi compagni nelle terre d'oltremare, non possiamo dirlo con sicurezza. Quando furono riferiti al beato Francesco il martirio, la vita e la leggenda dei suddetti frati, sentendo che in essa si facevano le lodi di lui, e, vedendo che i frati si gloriavano del martirio di quelli, poiché egli era il più grande disprezzatore di se stesso e sdegnava la lode e la gloria degli uomini, rifiutò tale leggenda e ne proibi la lettura dicendo: „Ognuno si glori del suo proprio martirio e non di quello degli altri«. E così tutta quella prima missione non approdò a nulla, forse perché non era ancora giunto il momento di mandarla poiché »il tempo di ogni cosa è designato dal cielo"” (Cronica di Giordano da Giano nr. 2329-2330 [7-8]).

5 A jelen tanulmányban használt kiadás: Chronica XXIV generalium ordinis minorum (1897). Tomus III., Bonaventurea, Romae.

[online] [2019. 12. 22.] https://gallica.bnf.fr/ark:/12148/bpt6k114485d/f2.image.texteImage 
közölt a szentekről, ha nem kötelezően megtartandó ünnepröl volt szó. ${ }^{6}$ Témáját és felépítését tekintve megfelel a szentekről szóló sermók általános jellemzőinek: a vértanúságtörténethez kapcsolódó írás a morális, illetve dogmatikai témákat és érveket helyezi a középpontba (cf. BÖRÖCZ 1911, pp. 83-84). Sajátosságát az jelenti, hogy a kanonizációt (1481) követő időszakban jelent meg, megírásának oka pedig a ferences növendékképzésben játszott szerepe lehetett. A Németországban megjelent korabeli sermonariumokban a kutatás jelenlegi állása szerint nem szerepelnek ezzel a témával foglalkozó prédikációvázlatok, a vértanúság jelentőségének hangsúlyozása tehát Pelbártra, vagy tágabban értelmezve a magyarországi ferences prédikációkra jellemző egyéni sajátosság lehetett. (Felvetődik annak a lehetősége is, hogy a beszédet a Mohácsot megelőző évtizedek - az oszmán terjeszkedésre különböző szempontokból reagáló - írásos megnyilvánulásainak kontextusában értelmezzük.) A beszéd azokat a morális szempontokat gyüjti össze három mysterium köré szervezve, amelyek miatt a vértanúk példaképül szolgálhatnak, elsősorban az első rend tagjai számára (amire vonatkozóan további támpontot nyújt, hogy a konklúzió alapját a regula, illetve a hármas fogadalom jelenti). ${ }^{7} \mathrm{~A}$ beszéd szerkezetét tekintve két jól elkülöníthető részre osztható: az első rész a vértanúság fogalmát pasztorális, illetve morális szempontok szerint tárgyalja, majd pedig ezeket a szempontokat a történeti események elbeszélése során alkalmazza. Pelbárt valószínűleg ismerte Szent Bonaventura vértanúkkal foglalkozó prédikációit, de csak közvetett forrásként számolhatunk velük, a sermo felépítésére nem gyakorolnak közvetlen hatást. A themát a Prédikátor könyvéböl vett idézet jelenti (a plantatio cedri a ferences sermonariumok közül Bernardino de’ Bustis müvében szerepel a Szüzanyára vonatkoztatva, az ószövetségi forrás megnevezése nélkül, így a Pelbárt-sermo forrásai között ez a szöveghely csak érintölegesen szerepelhet). ${ }^{8}$

A verba thematist jelentő három mysterium (corona, sanctimonia, gloriae altitudo) képezi a beszéd vázát. A thema kifejtésének első szakaszában Pelbárt arról értekezik, hogy miért lehet szentnek tekinteni az öt mártírt: egyrészt a vértanúság kiemelkedő volta miatt, másrészt pedig, mivel a ferences első rend tagjaiként Isten a megszentelt életre hívta meg őket - a tökéletes szentség jelképe pedig a cédrus, amelyre a magyarázatot egy természettudományos ismereteket közlő szentírásmagyarázó glossza adja meg. A corona a testvéri közösséget állítja a középpontba, és a cédrus magasságát alkalmazza szimbólumként, ${ }^{9}$ a plantatio (gloriae beatitudo) mellett pedig a mons Libanus (splendor) az üdvösség jelképe. Az első divisio témáját a corona, vagyis a vértanúság koszorújának bemutatása jelenti, amely Nagy Szent Gergelynek az apostolok életét témául választó egyik homíliájára támaszkodik. Pelbárt ebből azt a szakaszt emeli ki, amely Isten választottainak tulajdonságairól szó. A tulajdonságok közül vértanúkra jellemző hősiességet állítja a figyelem középpontjába, amelyet morális ellenpéldaként rögtön követ a korabeli keresztények tétlensége (retorikai szempontból ezt a szakaszt a kis ideig tartó, kevés szenvedés és a nagy dicsőség szembeállítása, valamint az ördögnek és a testi vágyaknak az egymással egyenértékü bemutatása határozzák meg, amelyek szintén szerzetesi hallgatóságot feltételeznek). ${ }^{10} \mathrm{~A}$ vértanúság hősiessége és az ezzel szemben álló tétlenség ellentétének kérdésre Órigenész Szentíráskommentárjából kiindulva próbál választ adni, amely három fő okot tételez fel a jelenség hátterében: magát az embert, a sátánt és Istent. A sermo ezekre az okokra építve mutatja be a vértanúság három

6 Pelbárt a Pomerium prológusában a következőket írja: „Pro cuiuslibet sancti colendo festo apud nos quattuor sermones applicare curavi. De festo autem non colendo unicum sermonem feci et hoc pro praecipuis dumtaxat sanctis, ubi et dum de his placuerit praedicare" (cf. BÖRÖCZ 1911, pp. 83-84).

7 A beszéd hét divisióra van felosztva, amelyek mindegyikét egy-egy morális szempont vezeti be, az első divisio azonban az események kezdeteinek elbeszélésével indul, és kiemeli magának Ferencnek a szerepét.

8 „Quasi cedrus exaltata sum in Libano” (BuSTI 1503, Pars IV/O).

9 Cf. THEODORETI 1769, p. 1418: ,, altitudo cedri, et fortis quasi quercus, et abstuli fructum eius desuper, et radices eius deorsum".

10 A tétlenség (acedia) bünének hangsúlyozása szintén szerzetesi célközönséget feltételez (cf. BÁRCZI 2007, p. 49). 
lehetséges útját, illetve ezek elutasításának okait. Az első okot - az emberi középszerüséget és az ebből fakadó tétlenséget - Pelbárt több szempontból is a vértanúkra jellemző tettrekészséggel állítja szembe.

Ezt követően Nagy Szent Gergely egy másik, De virginibus címet viselő homíliájából vett idézet segítségével azt fogalmazza meg, hogy a testi kívánságokról való lemondás nélkül a vértanúság lelkülete sem elérhető (a következö, Máté evangéliumából vett idézet viszont már a nem keresztény környezetben történő fizikai vértanúság lehetőségét vetíti előre a hallgatók, illetve az olvasók számára). A második okot, a sátán irigységét és ebből fakadó cselekedeteit, amelyek miatt az ember elveszítheti a lehetőséget, hogy részesedjen a vértanúságban, a beszéd ismét Nagy Szent Gergely kijelentésével ellensúlyozza, amely szerint a türelem gyakorlása és megőrzése által a lelki vértanúság elérése is lehetséges. Pelbárt Clairvaux-i Szent Bernátra alapozva, az önkéntes szegénységet, mint a lelki vértanúság kiváltságos útját jelöli meg, amely szintén a beszéd ferences célközönségére utal. A harmadik okként Isten irgalmát tételezi fel, mivel Ö meg szeretné kímélni az embereket a vértanúsággal járó szenvedéstől, és a bűnbánatra és a bünöktől való tartózkodás útjára hívja őket (a bünbánat jelentőségének hangsúlyozása szintén sajátosan ferences témát jelent).

A sermo a továbbiakban a Zsidóknak írt levél mellett ismét Nagy Szent Gergelyre és Clairvaux-i Szent Bernátra hivatkozik: ezek a szövegek szintén a testi vágyaktól való eltávolodásnak a vértanúsággal való párhuzamba állítását hangsúlyozzák (a történeti kontextussal is kibővítve), tehát szintén a szerzetesi hallgatóság érdeklődésére tarthatnak inkább számot. A corona (fratrum) kifejezést Pelbárt eltérő módon használja más szerzőkhöz képest: Clairvaux-i Szent Bernát sermonariumának 20. sermója a kifejezést az apostolokra érti. ${ }^{11}$ Karthauzi Szent Dénes Szent Pál-kommentárja szintén az apostolokkal mint Krisztus koronájával hozza kapcsolatba az ószövetségi képet (a kortárs forrás annak az értelmezésében is segítséget nyújt, hogy Pelbárt és hallgatói vagy olvasói milyen egyéb jelentésrétegeket kapcsolhattak testvéreik vértanúságához). ${ }^{12} \mathrm{~A}$ ferences hagyományban szintén megjelenik a corona fratrum témája: többek között Szent Bonaventura regulakommentárjának 8. fejezetében a miniszter generális és a testvérek kapcsolatát jellemzi az idézettel:

\section{„Circa illum corona fratrum quasi plantatio cedri in monte Libano."}

(BONAVENTURA 1596, p. 348) 13 $^{13}$

Végül a corona fratrum és a vértanúság összekapcsolása Johannes Gersonnál szerepel: ,, Corona fratrum septena / Refulget ob legis zelum" (GERSON 1706, col. 788), amiböl arra következtetünk, hogy a beszédnek ezt a szakaszát ő inspirálhatta.

A szentség (sanctimonia) tökéletességét központi témaként tárgyaló második divisio fő forrásait a Szentírás és Órigenész jelentik, azonban a szentség ferences útja is megjelenik a Szent Bonaventurahivatkozások által. A sermo írója a szentségnek a cédrusra alapozó, a Zsoltárok könyvére támaszkodó meghatározása során Cassiodorus kommentárjának abból a szakaszából indul ki, amely a cédrus botanikai jellemzőit foglalja össze, majd erre a természettudományos alapra építve közli az allegorikus magyarázatot (az érvelés itt kevésbé kidolgozott, Pelbárt megelégszik azzal, hogy konklúzióként megfeleltesse egymásnak a cédrus magasságát és a testvérek szentségének kiválóságát - olyan ténynek tekinthette ezt, amely nem szorul különösebb bizonyításra). ${ }^{14} \mathrm{~A}$ hármas fogadalommal (paupertas,

11 „Haec corona fratrum stetit in circuitu Iesu sicut scriptum est” (BERNARDUS 1520, p. 706).

12 „Iuxta illud Ecclesiastici, circa illum corona fratrum quasi plantatio cedri in Libano. His sanctis apostolis, velut splendidissimis stellis, fulgorem sapientiae, ardoremque charitatis mittentibus ornabatur Ecclesia, quorum doctrina ac imitatione decorantur animae Christianae in mente" (DIONYSIUS 1537, p. CXXIII/BC).

13 A corona fratrum-képet a Celanói életrajz is alkalmazza Ferenc szentté avatása kapcsán a pápát körülvevő bíborosokra vonatkozóan (cf. 1Cel 2,126).

14 A cédrus magassága és a szentség több patrisztikus és középkori forrásban is összekapcsolódik egymással. Szent Ambrus Énekek éneke-kommentárjában a cédrus magassága az igaz embert jelképezi, Szent Jeromos zsoltárbreviáriuma pedig a libanoni cédrushoz hasonlítja a szenteket érdemeik kiemelkedő volta miatt. Alanus de Insulis (Distinctiones dictionum theologicalium) a cédrus magasságát a szentség allegóriájaként alkalmazza, míg 
castitas, oboedentia) is kapcsolatba hozza a cédrust, hozzájuk kapcsolva a növény egyes jellemzöit, illetve a rájuk vonatkoztatható fogadalmat. A szegénységi, tisztasági és engedelmességi fogadalmakra és azok megtartására alapozó tökéletes szentség képe a cédrus magassága.

A cédrus szépsége az evangéliumi tökéletesség szépsége által meghatározott szegénységi fogadalmat jelképezi. A párhuzam alapját itt a ferences első rend regulája jelenti, tehát Pelbárt a cédrusnak a szerzetességre, illetve a vértanúságra való vonatkoztatásában Szent Antal említett sermóját követi. A növény szépsége - Szent Ágoston nyomán - a kereszten függő Krisztus szépségének felel meg (ennek a megjelenítője a három szög - Pelbárt ezeket felelteti meg a hármas fogadalomnak, amely egyben a Megváltó tökéletes utánzását is jelenti). A cédrus magasságát végül a testvérek szegénységével (paupertas) állítja párhuzamba, a sublimitas és a celsitudo fogalmainak megfeleltetésével (az utóbbi fogalom a Regula szövegében szerepel). A cédrus egyéb tulajdonságai - például az illata -, is a szegénység vonzó jellegének allegóriáját jelenti. ${ }^{15} \mathrm{~A}$ tisztaság (castitas) fogalma szintén a cédrus illatához kapcsolódik, itt a növény a kígyókat és legyeket elüző tulajdonságát emeli ki a szöveg Orosius Énekek éneke-kommentárjára hivatkozva. ${ }^{16} \mathrm{Az}$ engedelmességi fogadalom tárgyalásakor Pelbárt a cédrus gyógyító hatását emeli ki, arra az okra visszavezetve ezt, hogy Krisztus keresztjének egy része is cédrusból készült. Az engedelmesség, a kereszt és a vértanúság fogalmai a sermo ezt követő szakaszában különböző szempontokból kapcsolódnak össze egymással: az engedelmesség a legkiválóbb erények egyike, illetve minden erény forrása és őre, gyógyító hatással bír testi és lelki értelemben egyaránt. Végül a vértanú testvérek engedelmességét Krisztuséval állítja párhuzamba, a szenvedés engedelmességből vállalt önkéntes voltát pedig történeti kontextusba helyezi a muszlim vallási szokásokhoz kapcsolva. Az engedelmesség és a vértanúság, illetve az egymással történő összekapcsolásuk témáját Pelbárt további bizonyítékokkal támasztja alá, ami a kérdés jelentőségét mutatja a korabeli magyar első rendi obszervánsok számára. Az érvelést négy idézet - két ferences szöveg, illetve egy-egy szentírási és patrisztikus idézet - támasztja alá, a záró következtetés pedig azt hangsúlyozza, hogy az elnyert jutalom nagysága az engedelmesség gyakorlása közben tanúsított lelkülettől függ, és ebből következően a vértanú testvérek kettős jutalmat nyertek. A vértanúság kiválóságának további tényezőit az isteni kinyilatkoztatás, a hit megvallása, az önkéntes szenvedés, a hit megvallása és hirdetése, a vértanúság vágya, a kivégzés kegyetlensége, végül pedig a halálukat követő csodák jelentik.

A harmadik divisio szövegében, amely a testvérek alázatát szintén Krisztus alázatával párhuzamba állítva mutatja be, Pelbárt megkezdi vértanúságuk történetének ismertetését. A dicsőségük nagyságának (gloriae altitudo) végső oka a vértanúság vállalásának története, amely más vértanú-sermóktól eltérően nem Legenda megjelöléssel szerepel (mindez arra utal, hogy Pelbárt nem olvasandó, tanulságos történetnek, hanem személyesen követendő példának tekinthette a leírtakat). A hit megvallásával és a

Anselmus Laudunensis számára a cédrus magassága az erények kiválóságát jelképezi. A Jézus Krisztus és Mária szentségére utal vonatkozások mellett, másokra vonatkozan a szentséggel való kifejezett összekapcsolására kevés példát találhatunk, a cédrus legtöbbször az igaz ember jelképeként szerepel.

15 A cédrus illatára vonatkozóan szintén Szent Jeromos zsoltárkommentárja, illetve Izajás-kommentárja közöl hivatkozásokat. A cédrus illatára vonatkozóan a középkorban fontos változást jelentett, hogy jó illatát a Szüzanyára vonatkoztatták, és ezáltal több mariológiai müben szerepel, például Alanus de Insulisnál, aki ebben a kontextusban alkalmazza a kifejezést a szentekre vonatkozóan is, vértanúkkal kapcsolatos hivatkozás azonban a kutatás jelenlegi állása szerint nem fordult még elő. A 16. század botanikai szakkönyvei mellett a teológiai tárgyú munkákban is előfordulnak erre vonatkozó utalások, amelyek számos esetben kontinuitást mutatnak a középkori szövegekkel.

16 A patrisztikus forrásokban nem szerepelnek utalások a cédrus illatának kígyóűző tulajdonságára vonatkozóan, amely az ókori latin nyelvü irodalomban a Naturalis historiában tölt be fontos szerepet. Alanus de Insulisnál a cédrus illatának ez a tulajdonsága a szent esetében annak felel meg, hogy szavával, példájával és tetteivel elüzi a kígyókat, vagyis a démonokat. A szentséghez, illetve a szentekhez való kapcsolása nem minden szerzőre jellemző, például Angelomus Luxovensis illetve Anselmus Laudunensis csupán a tulajdonságról tesznek említést. 
prédikációval foglalkozó rész (amelynek a kiindulópontja a Krisztus által önként vállalt szenvedéssel való párhuzam) a történetnek azt a szakaszát idézi fel, amikor a testvérek Szent Ferenc megbízásából a szultáni palotában prédikálnak. A beszéd hatására az uralkodó elöször ki akarja végeztetni, majd fia tanácsára börtönbe záratja őket. Amikor a toronyból is folytatják a prédikálást, először másik cellába záratja, majd vissza szeretné őket küldeni Hispániába. Ennek a szakasznak a része a történet új szereplőjének, Péter (Pedro) infánsnak a bemutatása.

A vértanúságra való folyamatos törekvést Pelbárt szintén a szoros krisztuskövetés egyik útjaként mutatja be. Ennek a konkrét megvalósulási formáit a Marokkóba való visszatérési kísérletek jelentik. Ekkor kerültek másodszor is fogságba, majd az uralkodó ismét visszaküldte őket keresztény területre. Útközben a szökési kísérletek miatt Péter infáns magával vitte és őrizet alatt tartotta őket. Amikor ütközetre indult és több napon keresztül nem találtak vizet, a testvérek egyike forrást fakasztott (a történetnek ez az eleme újabb bizonyítékként szerepel a szentségükre vonatkozóan). A vértanúság kegyetlen módja ismét lehetőséget kínál arra, hogy a sermo Krisztus szenvedésével állítsa párhuzamba vértanúságuk történetét, amelyet részletesen be is mutat egészen a végkifejletig, amikor a szultán személyesen fejezi le őket. Végül Pelbárt a szentségükre vonatkozó döntő érvekként a kivégzésük után bekövetkezett csodákat foglalja össze.

A Chronica generalium ordinis minorum szövegével összevetve a beszéd legszembetünőbb sajátossága a krisztológiai párhuzamok közvetlen megjelenése, a vértanúság passiótörténetként való bemutatása (ennek az értelmezésnek lehetett a része az is, hogy a forráshoz képest kisebb részletességgel közölte a testvérek halálára vonatkozó konkrét részleteket). Pelbárt ezzel a módszertani megoldással azt az ókorban gyökerező hagyományt követi, amelynek kiemelkedő példáját a Szent Katalin-passiótörténet jelenti. A forrásszöveghez képest kisebb, de fontos eltérést jelent, hogy nem az elöljáró szerepe a hangsúlyos az útra indulásukat tekintve, hanem az isteni kinyilatkoztatás; szintén kisebb, de lényeges elemet jelent a csoda szerepének kiemelése. A szövegbővítés során tapasztalható másik jelenség az ismeretek átadása olyan területeken, amelyek a beszéd célközönsége számára kevésbé lehettek ismertek: ezek közé tartozik az infáns szó jelentésének magyarázata, vagy annak a fejtegetése, hogy miért nem engedték be a mecsetbe a testvéreket Marokkóba való érkezésük után.

A korabeli magyar ferences obszervancia helyzetére vonatkozóan a beszédből levonható legfontosabb következtetés az, hogy ekkor is döntő kérdést jelentett a regulához, a fogadalmakhoz és az evangéliumi élethez való hüség megtartása, ugyanakkor az oszmán terjeszkedés következtében várható, fenyegető változásokra való felkészülés, az azokra adható lehetséges válasz is. ${ }^{17}$ Ezt az értelmezést támasztja alá, hogy Pelbárt a Chronica szövegéhez hozzáadja az elöljárónak való engedelmesség témáját és a hitetleneknek történő állandó igehirdetést. A fö forrást jelentő krónika eredeti szövegéhez képest itt kevésbé hangsúlyos a világi keresztények magatartásának bemutatása, amiből arra következtethetünk, hogy a beszédnek nem ők voltak az elsődleges célközönsége, hanem az első rend tagjai. A beszédre alapozó magyar nyelvü prédikációk elhangozhattak ugyan a budai ferences templomban tartott szentmiséken, azonban elsődlegesen a prédikátorok és rendtagok számára írt buzdító munka is lehetett, azt a korábbi feltételezést kiegészítve, amely a ferences növendékképzésben játszott szerepét valószínüsíti.

17 A török veszély felismerése, a vele való szembenézés már a 15. század kezdetétől jelen volt és formálódott az európai gondolkodásban. A törökről mint legfőbb ellenségről alkotott negatív kép már a kezdeti időszakban kialakult, de ekkor még a pogánynak tekintett balkáni népekkel együtt említették őket. A 15. század második felében, a fenyegetettség fokozódásával a török-képben eszkatologikus elemek jelentek meg, ami a vértanúság lehetőségét is felvetette. A magyar származású Georgius de Hungaria Tractatus de moribus conditionibus et nequicia Turcorum címú munkája személyes tapasztalatokra alapoz, ami egyúttal a 16. század emberére is jellemzö, a török életmódja, szokásai iránti érdeklődésre mutat rá, amelynek hatása Pelbárt jelen sermójában is tetten érhetö (FODOR 1997, ÖZE 1991). 


\section{A sermo latin szövege}

\section{PH 061b}

[Pelbartus de Themeswar: Sermones de sanctis, Pars hiemalis

\section{Sermo LXI.b]}

\section{De sanctis martyribus quinque fratribus ordinis minorum}

\section{Corona fratrum quasi plantatio cedri in monte Libano. Eccl. I. caput ${ }^{18}$. (A)}

Quibus verbis convenienter de istis sanctis martiribus fratribus ordinis minorum pro hac solemnitate acceptis merito in ipsis Deum laudamus, sanctorum quoque gloriam predicamus. Nam ipsi fuerunt vere coronati corona martirii quae est praecellentissima inter aureolas; fuerunt etiam vere fratres minores ordinis beati Francisci, et denique fuerunt viri perfectissimae sanctitatis, propter quod merito comparantur cedris. Nam glossa III. Regum dicit sic:

\section{„Cedrus arbor imputribilis, odoris iucundi, aspectus nitidi, serpentes accensa vigore fugans et perimens, quae perfectis conveniunt, quorum insuperabilis patientia fama virtutis eximia, praesentia bonis gratissima, auctoritas ad confutandos veritatis inimicos constantissima."}

Haec glossa. ${ }^{19}$ Exquo itaque haec sanctitatis et perfectionis praeconia in ipsis beatis martiribus quinque fratribus ordinis minorum praefulserunt; idcirco ad eorum gloriam pro sermone convenienter accipimus haec verba thematis: corona fratrum scilicet minorum martyrorum quasi et est. In quibus verbis tria mysteria notabimus quod de his commendantur.

1. De coronae habitudine, ibi, corona fratrum;

2. De sanctimoniae altitudine quasi inquit cedri quae est arbor altissima;

3. De gloriae beatitudine cum dicitur plantatio in monte Libano, quod interpretatur candor, et ideo significat splendorem gloriae supernae. (B)

Circa primum de corona martirii quam habent isti sancti fratres sit pro conclusione verbum Gregorii in omelia de apostolis dicentis sic:

„Ecce electi Dei carnem domant, spiritum roborant demonibis imperant, virtutibus coruscant, praesentia despiciunt, ad eternam patriam currunt, atque ad illam per tormenta pertingunt."

\section{(GREGORIUS 1878b in PL 76,1207B; cf. LASKAI)}

Qua in re nostra segnicia reprehenditur cum pro ineffabilis gloriae corona nec parvum laborem sufferre volumus ut contra diabolum viriliter pugnemus, et contra carnalia desideria militemus. Quaestio ergo occurit hic: unde est quod nunc paucissimi nostrum patiantur pro Christo Iesu martirium, nec curant assequi tam excellentissimum coronae caelestis praemium, cum tamen olim sancti Dei et fideles Christiani mutuo se perire festinabant ad supplicium pro Christo sustinendum. Ad haec respondetur secus Origenem et glossam super Numerorum XVIII. caput quare hoc accidit tribus ex causis potissime

Cf. Eccl. 24,17 in Clementine Vulgate 2005: „Quasi cedrus exaltata sum in Libano”.

19 A kérdéses mủ nem a Glossa ordinaria, hanem Angelomus Luxovensis (†855) Királyok könyveihez írt kommentárja (Enarrationes in IV libros Regum). „Cedrus namque arbor est imputribilis omnino naturae, odoris iucundi, aspectus nitidi, serpentes accensa nidore fugans ac perimens. Quae universa perfectis quibusque conveniunt, quorum insuperabilis est patientia, fama virtutum eximia, praesentia cunctis gratissima, in bonis auctoritas, ad revincendos, confutandosque eos, qui veritati resistunt, constantissima, et qui in hac vita et in futura, singulari prae ceteris sanctis eminentia, fulgent" (ANGELOMUs, 1565, p. 133). 
inter caetera. ${ }^{20}$ Prima causa accipitur ex parte nostri, quia tam tepidi facti sumus et tam modici in virtutibus, quod tam magnam gratiam non meremur nec digni sumus pro Christo pati persecutiones. $\underline{\text { Nam ut etiam Gregorius dicit in omelia de virginibus, }}$

„,martir mori pro Domino non potuisset in corpore, si prius desideriis terrenis mortuus non fuisset in mente. ${ }^{21}$ Sed quoniam nondum non sumus mortui desideriis terrenis funditus, idcirco non sumus digni pati pro Christo."

Hinc auctor libri de interna conversione dicit sic: ,, O homo utinam dignus esses aliquid pro Iesu pati, ${ }^{22}$ beatus enim qui potuit pati pro Christo" ipsomet teste Matthaeo V.,

„, beati inquit estis cum maledixerint vobis homines et persecuti vos fuerint et dixerint omnem malum adversus vos mentientes propter me. Gaudete et exultate, quoniam merces vestra copiosa est in caelis; sic enim persecuti sunt et prophetas qui fuerunt ante vos et caetera." (Matth. 5,11) (C)

Secunda causa vel ratio est ex parte inimici, quia diabolus sciens ${ }^{23}$ homines qui per martirium consequerentur maximam coronam beatitudinis, invidens non vult nobis movere talem persecutionem ut impedimentum praestet nostrae felicitati ne habeamus illud summum bonum quod ipse perdidit, ideo glosa super numeri quo supra, dicit sic:

„Non meremur persecutorionem pati propter Christum. Sciens enim diabolus per
passionem martirii remissionem peccatorum fieri, non vult nobis per
persecutionem gentium publicam movere, quia invidet gloriae nostrae." 24

Haec glossa, ut habetur libro Originalium capite de martirio, sed qualiter in hoc diabolum supplantemus, ne omnino felicitate saltem spiritualis martirii careamus, edocet Gregorius in omelia de martiribus dicens sic:

„Duo sunt martirii genera, unum in mente in occulto, alius in mente simul et actione. Itaque martires esse possumus etiamsi ferro non trucidemur, mori quippe a a persequente martirium est in aperto opere, ferre vero contumelias odientem diligere martirium est in occulta cogitatione."

Et infra, ,sine ferro inquit martires esse possumus si patientiam in animo veraciter custodimus". ${ }^{25}$

20 Patristik Bible Commentary. Glossa Ordinaria; Biblia cun glossa ordinaria 1481.

21 GREGORIUS in Breviarum Laudunense 1839, p. 509.

22 Pelbárt itt Kempis Tamás Krisztus követése című munkájára hivatkozik, amelyet Máté evangéliumának segítségével értelmez, amikor a Krisztusért való szenvedést az üldöztetés különféle módjaival azonosítja (cf. KEMPIS Lib. II., Cap. XII,13).

23 A kifejezés - teljesen más szövegkörnyezetben és céllal - szintén szerepel Sienai Szent Bernát egyik sermójában (Sermo VIII. De amore miraculoso); a két szövegrész összevetése által képet kaphatunk arról, hogy a ferences prédikátorok milyen sokrétüen dolgozták fel az emberi gyengeséget ismerő gonosz lélek témáját: ,,diabolus sciens fontem aegritudinis, et sciens herbas illi infirmitati appropriatas, cum subtili astutia imponet infirmo dormienti in loco laeso et liberabitur, et sic infirmus dabit fidem percantulo, et diabolata anus iactabit se quod liberavit infirmum, quem medici non poterant liberare, et sic isto modo diabolus creditur, colitur, et adoratur, et detrahit honori Dei, qui solus adorandus est et colendus" (BERNARDINI 1745, p. 176).

24 A Pelbárt által a befejezését tekintve jelentősen átalakított szöveg Órigenésztől vett idézet: „,non enim meremur persecutionem pati propter Christum, nec mori propter nomen Filii Dei. Et ideo etiam diabolus sciens per passionem martyrii remissionem fieri peccatorum, non vult nobis publicas gentilium per persecutiones movere, scit enim quia, si ad reges et praesides adducamur propter nomen Christi, ad testimonium Iudaeis et gentibus, gaudium nobis et exultatio sit, quia merces nostra multa in coelis est. Haec non facit inimicus, vel quod ipse gloriae nostrae invidet" (ORIGENIS 1844, pp. 353-354).

25 A csaknem szó szerint átemelt idézet a Szent Jakab apostol ünnepére írt egyik sermo része, amelyben Márk evangéliumának a következő perikópáját magyarázza: „Zebedeus fiai, Jakab és János eléje járultak, s megszólitották: »Mester, szeretnénk, ha teljesitenéd egy kérésünket. «»Mit tegyek nektek?" - kérdezte. »Add meg 
Haec Gregorius, item hoc idem edocet Bernardus in sermone qui incipit festivitas, dicens sic: „eadem promissio facta est pauperibus quae et martiribus videlicet, quia Salvator dixit, beati pauperes spiritu quoniam ipsorum est regnum caelorum, et idem ait, beati qui persecutionem patiuntur propter iustitiam, quoniam ipsorum est regnum caelorum; ecce utriusque regnum idem promittitur."

(BERNARDUS 1862 in PL 183,462B)

Rationem subdit Bernardus quia vere inquit martirii genus est paupertas voluntaria, nam quod martirium gravius est quam inter epulas esuriae, inter vestes multas algere, paupertate premi inter divitias quas desiderat noster appetitus. An non merito coronabitur qui sic legitime certaverit, haec ille: ,sic ergo diabolum supplantamus ut videlicet felicitatem aliquo modo martirii adquiramus". (D)

Tertia causa vel ratio ex parte miserentis Dei, qui sciens nostram modicitatem et infirmitatem nobis parcit propter suam bonitatem et misericorditer condescendit, iuxta illud psalmum: ,, quomodo miseretur pater filiorum misertus est Dominus timentibus se, quoniam ipse cognovit figmentum nostrum" (Psalm. 103,13-14). Ne tamen omnino careremus celesti gloria voluit nobis Dominus tanquam pius pater levius martirium quod possumus nos ipsi facere nobis carnis nostrae mortificationem et peccatorum expiationem per veram penitentiam ac vitiorum cautionem, ut saltem in hoc conformemur Christo passo pro nobis, et ei satisfaciamus. Propterea apostolus hortatur omnes Christianos Hebraeorum XII dicens:

„Recogitate eum scilicet [...] Christum qui talem sustinuit a peccatoribus adversus se ut non fatigemini animis vestris deficere. Nondum enim usque ad sanguinem restitis adversus peccatum repugnantes, " (Hebr. 12,3-4)

\section{et ad Galatas V.:}

„Spiritu ambulate et desideriis carnis non perficietis. [...] Qui enim Christi sunt, carnem suam crucifixerunt cum vitiis et concupiscentiis et caetera."

(Galat. 5,16.24)

Proinde et Gregorius in omelia loquente Iesu ad turbas, dicens sic:

„Quamvis occasio persecutionis desit, habet tamen pax nostra martirium suum si spirituali gladio carnalia desideria trucidamus. ${ }^{\text {26 }}$

\section{Item Bernardus, de re martirii}

„genus est quotidiana carnis mortificatio, illud quidem martirium quo ferro membra ceduntur horrore est immitius; istud vobis est diuturnitate molestius, haec ille quod ergo Christiane accipe exemplum ab ipsis sanctis martiribus quod dormitas, cur torpes, velis nolis mori debes, ex hoc saeculo exire cogeris, miseramque tuam carnem vermibus escam dabis. Cur igitur pro ea et cum ea animam perdere vis in aeterna supplicia? Castiga carnem, age paenitentiam ut cum martiribus possis gaudere in patria, sic bene tibi et animae et corpori provides. ${ }^{, 27}(\mathrm{E})$

nekünk - felelték -, hogy egyikünk jobb oldaladon, másikunk bal oldaladon üljön dicsöségedben «” (Mk 10,3537). A sermo Jakab apostol türelmét emeli ki elsőként, amelynek köszönhetően elnyerte a vértanúság koszorúját. A Pelbárt által hivatkozott eredeti szakasz szövege a következő: „, Duo quippe sunt martirii genera unum in mente, aliud in mente simul et actione. Itaque esse martires possumus etiam si nullo ferro percutiencium trucidamur. Mori quippe a persequente martirium in aperto opere est. Ferre vero contumelias, odientem diligere, martirium est in occulta cogitacione."

26 „Nam quamvis occasio persecutionis desit, habet tamen et pax nostra martyrium suum, quia etsi carnis colla ferro non subdimus, spiritali tamen gladio carnalia desideria in mente trucidamus, ipso adiuvante etc" (GREGORIUS 1878a in PL 76,1089).

27 BIVAR 1662, p. 128. 
Circa secundum de altissima sanctitatis perfectione qua isti beati martires fulserunt quod notatur in cedri comparatione quae est arbor altissima. Cassiodorus enim super psalmum XXVIII. dicit quod „,cedri quae alibi nascuntur non omnino procerae sunt, in Libano autem tales inveniuntur ut omnes altitudines arborum superare videantur". ${ }^{28}$ Haec ille. Unde accipiamus pro conclusione quod istorum martirum fratrum minorum sanctitas perfectissima pro regulari voto et observantia merito commendatur tanquam cedrus altissima. Declaratur haec conclusio ex regulae votis tribus:

primo ex voto paupertatis,

secundo ex voto castitatis,

tertio ex voto obedientiae et eius virtutis.

Primo ex paupertatis voto, nam Haymo super Canticum ait: „Cedrus inquit pulchritudine, fortitudine, sublimitate, odore, omne decus silvarum antecedit", haec ille. ${ }^{29}$ Revera sic paupertas fratrum minorum antecedit aliorum religiosorum paupertatem, primo pulchritudine evangelicae perfectionis, quomodo dicitur in $\underline{\text { regula: }}$

„Regula et vita fratrum minorum haec est, sanctum scilicet evangelium Domini nostri Iesu Christi observare vivendo in obedientia in paupertate et in castitate, et sic est ibi pulchritudo imitationis, similitudinis quoque ad Christum crucifixum. ${ }^{30}$

Dicit enim Augustinus , quod Christus ubique nobis pulcher occurrit, pulcher in praesepio et pulcher praecipue in ligno crucis". Nimirum sicut Christus confixus pependisset in cruce in uno clavo, tamen non tam pulchrum videretur, scilicet si duobus clavis adhuc minus pulcher quam in tribus fuisset. Sed pendens in cruce tribus clavis affixus pulcherrimus videtur devotae menti et fideli. ${ }^{31}$ Sic observantia regularis fratrum minorum in his tribus votis promissis Christum pulcherrime imitatur, ut dicere possit illud ad Galatas II. ,"Christo confixus sum cruci, vivo ego iam non ego, vivit vero in me Christus (Galat. 2,19); et sic patet de pulchritudine. Secundo, sicut cedrus exceditur fortitudine ut patuit, sic paupertas fratrum minorum fortitudine asperitatis vitae, quoniam ut dicit Clemens papa, ,tenent ad artum usum ", utpote paupertatis artissimae et caetera. Tertio sublimitate excedit cedrus, sic paupertas minorum dicitur altissima, quomodo beatus Franciscus dicit in regula:

"haec est illa celsitudo altissimae paupertatis quae vos clarissimos fratres mei
haeredes et reges regni caelorum instituit, pauperes rebus fecit, virtutibus
sublimavit haec sit portio vestra quae perducit in terram viventium.
.32

Quarto cedrus excedit odore ut patuit, sic paupertas minorum odore sanctissimae paupertatis attrabit animas sanctas plurimas ad devotionem et imitationem ut dicans.

$$
\begin{aligned}
& \text { „Trahe nos in odore ungentorum tuorum currimus adolescentulae id est ferventes } \\
& \text { in Christo animae." }
\end{aligned}
$$

CASSIODORUS 1589, p. 41; vagy in PL 70,200A.

HAYMO 1852 in PL 117,295-358D.

30 „Regula et Vita Minorum Fratrum haec est, scilicet Domini nostri Jesu Christi sanctum Evangelium observare vivendo in obedientia, sine proprio et in castitate" (Regula bullata $\mathrm{I}$.).

31 „Ubique enim Christus Dominus pulcher occurrebat: pulcher in coelis, pulcher in terris; pulcher in Patre Verbum, pulcher in matre caro et Verbum; pulcher in utero Virginis, ubi non amisit divinitatem, cum suscepit humanitatem: quia cum hic esset, cum manibus portaretur locuti sunt coeli, gavisi sunt Angeli, Magos stella direxit. [...] Pulcher ergo Christus in miraculis; in flagellis, in sermonibus, in verberibus pulcher; non curans mortem, et mortuos suscitans; pulcher in ligno, pulcher in coelo, pulcher et in sepulcro" (Sermo CXXVIII 5 in AUGUSTINUS 1838, col. 2680).

32 „Haec est illa celsitudo altissimae paupertatis, quae vos, carissimos fratres meos, heredes et reges regni caelorum instituit, pauperes rebus fecit, virtutibus sublimavit (cf. Jac 2,5). Haec sit portio vestra, quae perducit in terram viventium (cf. Ps 141,6)" (Regula bullata VI,4-5). 


\section{Dilexe te Canticorum I. (F)}

Secundo ex voto castitatis declaratur conclusio perdicta, quia ut dicit Orosius super Cantica, „, cedrus est arbor imputribilis, per odorem suum serpentes fugans et muscas et bene redolens”. Haec ille. Sic sancta castitas quam isti beati fratres voverant in regula contrariatur corruptioni carnis et fugare habet serpentes motus fomitis in carne, atque muscas malarum cogitationum carnalium ${ }^{33}$ et optime redolet coram Domino et angelis. Unde Canticus ultimus scribitur quod „,dilectus sanctus Christi libenter pascitur inter lilia castitatis". ${ }^{34}(\mathrm{G})$

Tertio ex voto oboedientiae, ut enim idem Onorius super Cantica dicit: „Cedrus habet resinam perstantiorem ceterorum, quia languida membra curat, vermes ulcerum necat, et a vermibus illesa manet adopertus, ${ }^{35}$ sicut glossa Ecclesiastici XXIV. testatur: „Libri liniti resina cedrina nec tinea nec senectute deficiunt", denique crux Christi fuit praesertim de ligno cedri, quoad truncum inferiorem stipitis crucis ut ferunt historiae. ${ }^{36} \mathrm{Et}$ notatur in Clemente de summa trinitate in glossa super verbo cruci, haec autem conveniunt dici de oboedientia istorum fratrum minorum quae est praestantissima virtus super omnes victimas, in Regum 15, ,, Melior est oboedientia quam victimae; ipsa enim languida curat membra spiritualiter, et vermes ulcerum necat", ${ }^{37}$ quia ut dicit Hugo de sacramentis libro I. paragrafo XI: ,, Quemadmodum omne vicium ab inoboedientia processit sic omnis virtus ab oboedentia incipit; item ipsa conservat a vermibus viciorum" ut dicit Augustinus de civitate Dei libro X: "oboedentia est mater et custos omnium virtutum". ${ }^{38}$ Praeterea sicut Christus crucem subiit ex oboedentia patris ut dicit Philippienses II., ,factus oboediens usque ad mortem, mortem autem crucis", 39 sic isti beati fratres ex oboedentia patris seraphici Francisci profecti sunt ad martirium ipsum sustinendum, ut patebit in legenda. $(\mathrm{H})$

Quaestio hic occurit, utpote isti beati fratres in suo martirio maiori sint laureati proemio pro oboediantiae merito. Respondet enim seraphicus Bonaventura in libro de profectu religionis quod ,omne bonum quod sit ex oboedentia est meritorium dupliciter" ${ }^{40}$ Uno modo pro ipso opere bono quod sit ex eius labore, iuxta illud apostoli, in Corinthiorum III. ,, Unusquisque propriam mercedem accipiet secundum suum laborem, alio modo meretur ex ipsa oboedientia quae talis et tantae virtutis est quod victimis quibusvis preferatur" iuxta $\underline{\text { Regulam XV }} .{ }^{41}$ Unde Gregorius in moralibus et notatur VII. quod sciendum dicit „, oboedientia victimis iure praeponitur quia per victimas aliena caro, per oboedientiam vobis propria voluntas mactatur". ${ }^{42}$ Et ut ibidem arguitur tanto maioris meriti obedientia ostenditur, videlicet quanto inoboedentia ariolandi peccatum monstratur. Insuper quanto gratiosius et acceptius bonum et voluntas Deo offertur in oboedentia, tanto amplius meritum comprobatur. Non ergo dubium

Cf. „Musca enim insolens et inquietum animal est in qua quid aliud quam insolentes curae desideriorum carnalium designantur" (MAURUS VIII,7).

34 Cf. BEDA 1844, p. 249.

35 Cf. HONORIUS in PL 172,382.

36 „Resina quoque eius qui cedrina dicitur liniti libri nec tinea nec senectute deficiunt et doctorum spiritali sensu scriptura confecta nulla hereticorum astutia corrumpitur vel vetustate consumitur" (Glossa Ecclasiastici XXIV,17).

37 Pelbárt itt valószínűleg egy kézzel írt glosszára utalhat, amelyet a De summa trinitate egyik példányában látott.

38 Az idézet hátterében az állhat, hogy Pelbárt összekapcsolt egymással két, Szent Ágostonnál, illetve Nagy Szent Gergelynél szereplő hasonló kifejezést, amelyeket a Forma cleri címü munka szerzöje az obedientia címszó alatt gyüjtött össze (lásd TRONSON 1824, p. 178).

39 „,Megalázta magát és engedelmeskedett mindhalálig, mégpedig a kereszthalálig” (Fil 2,8).

40 Cf. BONAVENTURA 1513.

41 Regula beati patris nostri Francisci 1502.

42 „Item cum de bono obedientiae tractaretur, in expos. B.Job I,35 adiunctum est: Melior est obedientia quam victima etc. Obedientia victimis iure praeponitur, quia per victimas aliena caro, per obedientiam vero voluntas propria mactatur" (GREGORIUS 1705, col. 144). 
quod isti sancti in martirio dupliciter meruerunt proemium usque aureolam martirii et specialem gloriam quasi torquentes pro oboedientia. (I)

Circa tertium de beatitudinis eorum gloria sit pro conclusione qui istorum sanctorum fratrum martirium imitando Christum multipliciter probatur fore gloriossissimum, et patet primo ex humili oboeditione. Sicut enim Christus humilissime obedivit Deo patri et accessit ad crucis martirium, sic isti humillime oboedientes Deo et beato patri Francisco accesserunt ad martirium, quod est pro maxima eis gloria ut dictum est supra. Anno quippe Domini MCCXXXVI a prima conversione Beati Francisci anno XIII mandavit Deus beato Francesco mittere aliquos fratres ad regnum Marochiorum ad praedicandum et martirium consequendum. De voluntate ergo Domini beatus Franciscus misit sex fratres mirae sanctitatis, vicarium fratrem Vitalem, quem praefecit caeteris in praelatum, fratrem Beraldum, fratrem Ottonem, fratrem Accursium, fratrem Petrum et fratrem Adiutum. Cum autem venissent ad regnum Aragoniae, frater Vitalis infirmatus est graviter, quam infirmitatem videns prolongari, et sic negotium impediri, ipse ibidem mansit, alii vero progressi sunt ad implendam oboedientiam. Secundo ex divina revelatione, sicut enim Christus providit et praedixit mortem sic isti. Cum enim dicti fratres quinque profecti pervenissent Colimbriam regina Portugalie Oracha nomine videns in eis tamen mundi contemptum et tantum fervorem ad moriendum pro Christo, eos devote suscipiens rogavit instanter ut Deum orarent quotenus vitae suae terminum revelaret. Qui cum dicerent se indignos ad exposcendum divina secreta, tandem ob devotas preces et lacrimas reginae exorantibus fide firma revelatum est eis divino oraculo non solum quod postulabant, sed insuper illorum martirium complendum, et eorum corpora illuc a Marochis deferenda, et ab ipsa regina cum toto popolo honorifice recipienda. Ipsi ergo haec omnia et extremum diem reginae prodixerunt et eo modo cuncta postea sunt impleta. (K)

Tertio ex voluntaria passione gloriosissimum probatur martirium ipsorum, quoniam sicut Christus voluntarie accessit ad patiendum, sic et ipsi habita revelatione praedicta accesserunt, et cum difficultate pervenerunt ad civitatem Saracenorum quae Sibilia dicitur, et tandem spiritu ferventes usque ad principalem templum ipsorum sine aliquo ductore venerunt, quod cum vellent intrare, Saraceni indignati eos clamoribus impulsibus et verberibus impetentes, nullatenus intrare permiserunt. Haec enim est eorum institutio ut nullis Christianorum aut sectae templum ipsorum ingredi permittant.

Quarto ex fidei professione et ferventi praedicatione, nam ut Christus pro evangelicae fidei praedicatione passus est, sic et isti. Unde tandem accesserunt ad portam palatii et ad regem, legatos se dixerunt a rege regum Domino Iesu missos, cumque regi illi de fide catholica multa propossuisent, et de Machometo ac eius lege damnabiles falsitates detexissent, iratus rex iussit eos truncari capitibus, sed ad verba filii sui mitigatus iussit eos in summitate turris recludi. Ipsi vero de turris altitudine Christi fidem omnibus curia egredientibus praedicabant, Machometum sectantes deceptos dicebant, et perire eternali. Tunc rex in fundo eiusdem turris illos inclusit, et postea seniorum consilio misit eos Marochium cum domino Petro qui erat Christianus, aliisque catholicorum. Dominus autem Petris infans dictus, sectos cum magna devotione in hospitio suo recepit et necessaria eis ministravit. Iste dominus Petrus dictus est infans, quia in Hispania filii regum post primogenitum infantes appellantur; tunc fratres illi ubique videbant saracenos eis serventissime praedicabant, cumque frater Beraldus quendam currum in foro ascendens populo praedicaret, Miramolinus rex inde transiens ad videndum regum sepulchra quae extra muros sunt, videns fratrem praedicantem, percepit ut omnes quintos fratres de civitate expellerent, et per Christianos ad partes fidelium sine mora remitterentur. Tunc dominus Petrus infans quosdam de suis servis conductores dedit, sicque coacti sunt exire inde. (L)

Quinto ex desiderio et iterata oblatione, nam sicut Christus obtulit se non semel adversaribus, sic et isti qui cum reducerentur, dimissis in via productoribus iterato sunt reversi Marochium, et coeperunt praedicare in foro. Unde rex eos in carcere inclusit, ubi sine cibo viginti diebus fuerunt sola divina consolatione refecti, postmodum accidit immoderatus calor et maxima intemperies aeris supervenit quod extimantes propter sectorum carcerem evenisse, rex Domini consilio eos liberavit e carcere Christianis 
percipiens quod ad partes Christianorum eos sine mora remitterent. Mirabant autem omnes quod viginti diebus sine cibo et potu incolumes mansissent. Cum autem ducerentur ad partes fidelium fratres, illis in via dimissis Marochium redeunt. Tunc habito inter Christianos consilio dominus Petrus infans illos in suo hospitio tenuit sub custodia ne in publicum prodirent. Post haec idem dominus Petrus missus est a rege cum exercitu contra quosdam rebelles Saracenos, et duxit secum sanctos fratres. Accidit autem quod per tres dies non potuerunt pro se et equis aquam ad bibendum alicubi invenire. Desperantes idcirco de vita, frater Beraldus oratione praevia accepto brevi pasillo terram fodit et statim fons erupit, de quo ad plenum homines et iumenta totius exercitus bibentes, et utres implentes, statim hoc fecit omen, fons exsiccatus est ut clarescat, qui non nisi divino miraculo inventa est ibi aqua. Omnes ergo percussi tanto miraculo ceperunt illos revereri et pedes eorum osculari. (M)

Sexto gloriosum extiti eorum martirium ex crudeli occisione, sicut enim Christus crudelissime est occisus, sic et isti licet alio gente paene, tandem ei reverso exercitu illo Marochium isti fratres clam domum exeuntes praesentaverunt se regi Miramolino audacter praedicantes Christum. Ille ira plenus percepit cuidam principi Saraceno ut illos capite truncaret. Missis ille apperitoribus iussit eos adduci alapis et ictibus percussos, tunc Christiani timore mortis ad propria hospitia confugerunt, quos adductos et in fide confessione firmos videns percepit variis tormentis torqueri. Tunc fortiter sunt flagellati, et tandem ligatis pedibus per terram huc et illuc tracti adeo sunt verberati quod fere viscere apparebant, et super ipsorum vulnera bulliens oleum et acetum fundentes super stramenta testarum volutabant, sic quoque per totam noctem a triginta Saracenis crudeliter sunt flagellati. Eadem nocte viderunt custodes quod lux magna de caelo descendit et sanctos fratres recipiens ad coelos cum innumerabili multitudine sublimabat; quidam visione stupefacti ad carcerem accedunt et eos devote orantes inveniunt. Rex vero Marochiorum auditus istis furore succensus ut sibi ducerentur percepit, quod expoliati ligati et fustibus continue acti ad regem ducuntur, rex autem ait eis: ,convertimini ad fidem nostram et dabo vobis pecuniam magnam et eritis honorati in regno meo ”; quibusdam etiam mulieribus introductis dixit: , has muliere dabo vobis in uxores”. Responderunt sancti: ,omnia propter Christum contemnimus et mori pro fide parati sumus"; tunc rex arrepto gladio sanctis separatis ab invicem uni post alium caput per medium frontis fregit, et tres gladios se invicem coniunctos constringens propria manu ferali crudelitate eos decollavit, et sic gloriosum compleverunt martirium. (N)

Septimo ex miraculorum multorum illustratione, e quibus alique breviter narremus; cum enim corpora eorum vellent Saraceni comburere ignis extinguebat per miraculum. Item ex Christianis qui erant indignati fornicatione tangere reliquias nisi prius confiterentur non poterant, sed aut ab eis levabantur in aera, aut illi viribus totis mox destituebantur. Tandem dominus Petrus infans invocans eosdem meruit ut sibi licentia a rege daretur redeundi ad Hispaniam, et tunc illas reliquias asportavit et in via plurimis a periculis per eas est liberatus. In mari etiam nocte tenebrosa timentes pericula et istos sanctos exorantes, mox claram lucem a Deo habuerunt, et sic salvi in Hispania devenerunt; fama autem audita domina Oracha regina cum universo populo occurrit reliquiis, et solenni honore in monasterio sanctae crucis de Colimbria collocavit, et ut sancti praedixerant ad Dominum regina migravit. Eadem hora noctis quidam canonicus Petrus sacrista confessor, reginae orans in ecclesia illa vidit innumerabiles fratres minores chorum intrantes, inter quos erat unus praecedens solemnissimus, et post alii quinque qui indicibili melodia matutinumm canebant. Attonitus ille quaesivit ab uno eorum unde intrassent cum fores et portare essent clausae. Qui respondit:

„,nos sumus fratres minores qui caelo iam regnamus cum Christo. Ille praecedens est beatus Franciscus, alii quinque sunt fratres isti martires; et scito quod hac hora regina Oracha migravit quae ordinem nostrum multum dilexit. Ideo nos misit Christus Iesus ad deferendam animam eius in caelum, et sic disperuit”.

Et ecce nuntius advenit dicens reginam migrasse, haec sufficiant. Rogemus ergo Christum ut istorum meritibus det nobis gratiam et gloriam. Amen. 


\section{A Chronica XXIV generalium ordinis minorum leírása}

Analecta Franciscana sive chronica aliaque varia documenta ad historiam fratrum minorum spectantia edita a patribus Collegii S. Bonaventurae (1897). Tomus III., Firenze, pp. 16-25.

Eodem tempore beatus Franciscus de voluntate Domini misit sex fratres perfectissimos ad regnum Marochiorum, ut infidelibus costanter fidem catholicam praedicarent, videlicet fratrem Vitalem, Beraldum, Petrum, Adiutum, Accursium et Othonem. Fratrem vero Vitalem eis dedit praelatum volens, quod sibi quinque alii obedirent. Cum autem fuerunt in regno Aragoniae, frater Vitalis coepit graviter infirmari et videns, prolongari suam infirmitatem, nolens, suo corporali languore Dei negotium impediri, praecepit aliis quinque praedictis fratribus, ut Dei et fratris Francisci praeceptum, pergentes Marochium, adimplerent. Sancti vero fratres obedientes, dimisso ibi fratre Vitale infirmo, Colimbriam perverunt. Domina vero Orracha, regina Portugalliae, quae tunc erat ibi, eos ad se vocans et cum eis de Deo loquens, videns in eis tantum mundi contemptum, tantum ad moriendum pro Christo voluntatis fervorem, illos existimans perfectissimos Dei servos rogavit eos instanter, ut a Domino orando postularent, ut eis suae vitae terminum revelaret. Cumque se humiliter excusarent, quod, cum essent peccatores, non erant digni, quod eis Dominus sua secreta revelaret, regina tam efficaciter et cum multis lacrimis sanctos fratres rogavit, quod se oraturos finaliter promiserunt. Orantes omnes, divino illustrato oraculo, reginae quae futura erant revelantes, dixerunt:
„Domina, non displiceat vobis quod Deus de vobis misericorditer definivit. Ipse enim per nos vobis denuntiat, quod post breve tempus vos ex hac vita subtrahet ante dominum vestrum regem. Et hoc accelerationis mortis vestrae indubitabile erit signum: sciatis enim pro certo, quod nos pro Christi fide breviter occidemur. De quo valde gaudemus, quia Dominus nos vult in numero suorum Martyrum computare. Cum autem apud Marochium finiverimus dies nostros, Christiani ad istam civitatem corpora nostra, ut ibi sepeliantur, portabunt, et vos cum populo isto exibitis ad nos recipiendum honorifice et devote. Et tunc, cum ista videbitis, sciatis, quae vobis praedicimus, veraciter adimplenda."

Et inde sancti procedentes, Alanquerium castrum devenerunt et dominae Sanciae, sorori regis Portugalliae supradictae, totum suum propositum revelarunt. Ipsa vero sanctissima eorum negotium approbans, induit eos super habitus saecularibus vestimentis, quia aliter non possent ad Saracenos transire. Et sic dissimulato habitu Hispalim, civitatem tunc Saracenorum, quae nunc Sibilia dicitur, pervenerunt, et in hospitio cuiusdam Christiani per dies octo, depositis vestimentis saecularibus, latuerunt.

Quodam vero die spiritu ferventes usque ad principalem mesquitam seu ipsorum oratorium sine aliquo ductore venerunt. Quod cum vellent intrare, Saraceni indignati eos clamoribus, impulsibus ac verberibus impetentes, intrare mesquitam nullatenus permiserunt. Tandem ad portam palatii accedentes, quasi ambaxiatores regi se fore missos dixerunt a Rege regum, Domino Iesu Christo. Cumque regi multa de fide catholica proposuissent, ipsum ad conversionem et suscipiendum baptismum inducendo, et multa turpia de Machometo et eius lege damnabili detexissent, rex quasi in furorem versus capitibus eos truncari iubet; tamen postea rex ad verba sui filii mitigatus iussit, eos in cuiusdam turris includi summitate. Illi vero de turris altitudine ingredientibus et egredientibus curiam fidem Christi praedicabant, legem Maurorum et eius observatores damnantes. Quod audiens rex eos praecepit in fundo turris carceralis includi; et post, habito seniorum consilio misit eos Marochium, sicut ipsi optabant, cum domino Petro Fernardi, nobili Hispano catholico, et quibusdam aliis Christianis. Et intraverunt hospitium, in quo morabatur supradictus dominus Petrus infans; qui sanctos fratres cum magna devotione recipiens fecit eis de victualibus providere. Tunc fratres, ubicumque videbant Saracenos congregatos, eis ferventissime praedicabant. Cum vero semel frater Beraldus quendam currum 
ascendens populo praedicaret, contigit, quod Miramolinus rex pergens ad videndum sepulcra regum, quae sunt extra muros, inde transibat. Qui videns fratrem praedicantem miratus, ipsum fatuum existimans, praecepit, cum pro eo nollet a praedicatione desistere, ut omnes quinque fratres de civitate expellentur et quod per Christianos remitterentur ad partes fidelium sine mora. Tunc dictus dominus Petrus infans dedit eis quosdam de servitoribus suis, qui eos ducerent usque ad Septam, et inde ad partes fidelium transfretarent. Sancti vero fratres, illis in via dimissis, Marochium revertuntur et civitatem ingressi statim coeperunt Saracenis in foro existentibus praedicare. Quod rex audiens praecepit, eos in carcere recludi; ubi sine cibo et potu viginti diebus fuerunt, sola divina consolatione refecti.

Postmodum accidit, quod immoderatus calor et magna intemperies aeris supervenit. Existimantes autem aliqui, quod propter carcerem sanctorum fratrum illa tempestas evenisset, rex de consilio Ababoturin, qui Christianos diligere videbatur, ipsos a carcere liberavit praecipiens Christianis, quod ad partes Christianorum eos remitterent sine mora.

Coepit tamen mirari cum aliis Saracenis, quando eos vidit corpore incolumes et mente constantes, cum tamen viginti diebus continuis fuissent in carcere sine cibo. Et cum liberi fuissent, statim voluerunt Saracenis proponere verbum Dei: sed Christiani timore regis nullatenus permiserunt, sed dederunt eis ductores, cum quibus versus partes fidelium remearent. Fratres vero, illis in via dimissis, Marochium revertuntur. Tunc habito consilio inter Christianos, dictus dominus Petrus infans eos in hospitio suo retinuit et prodire in publicum, adhibitis eis custodibus, non permisit. Post haec dominus Infans cum multis aliis Christianis et Saracenis, congregato exercitu, perrexit ad expugnandum quosdam Saracenos, qui regi nolebant obedire; et redeundo per tres dietas non potuerunt pro se vel equitaturis aquam ad bibendum alicubi invenire. Cum vero angustia sitis de vita desperarent, frater Beraldus, praevia oratione accepto brevi paxillo, fodit in terram, et statim fons erupit, de quo ad plenum biberunt homines et iumenta et utres etiam impleverunt. Et hoc facto statim fuit fons ille exsiccatus. Omnes vero, tanto miraculo viso, eos in maiori reverentia et devotione habuerunt, et multi eis habitus osculabantur et pedes. Cum vero reversi Marochium custodiretur, ut prius, quadam feria VI. per locum quendam insuspectum de domo exeuntes se Miramolino regi eunti ad visitandum sepulcra regum audacter praesentarunt; et frater Beraldus currum ascendens coepit praesente rege intrepide praedicare. Quo rex iracundia plenus praecepit cuidam principi Saraceno, qui miraculum aquae viderat, ut eos capitali poena puniret. Tunc omnes Christiani timore mortis ad propria hospitia confugerunt, ubi firmatis ianuis latitabant; quos etiam Saraceni tenebant ab extra circumclusos. Postea dictus princeps, missis apparitoribus, praecepit, eos ad se venire. Qui dum fuissent ad principis domum bis adducti, illo absente, ministri diaboli eis alapis et ictibus percutientes in maiorem carcerem recluserunt, et ibi sancti fratres Christianis et haereticis verbum Dei continue praedicabant. Tunc princeps fecit eos adduci. Quos cum invenisset constantissime fidem catholicam confitentes et iniqua Machometi et eius legis exprobrando audacter reserantes, ira magna succensus praecepit, eos variis tormentis torqueri et in diversis domibus ab invicem separatos fortiter flagellari.

Tunc iniqui ministri, ligatis manibus Sanctorum et pedibus, positis funibus in collis eorum, ipsos per terram trahentes et retrahentes, sic graviter flagellarunt, quod fere viscera apparebant, super ipsorum etiam vulnera fractis vasis ferventis olei et aceti, et vasorum fragmentis super ipsorum stramentis asperis positis, Sanctos super ipsa proiicentes et volutantes; sic per totam noctem afflicti et a triginta fere Saracenis fuerant custoditi et crudeliter flagellati. Eadem nocte fuit visum custodibus, quod lux magna de coelo descendebat et sanctos fratres recipiens ad coelos cum innumerabili multitudine sublimabat. Qui stupefacti et territi ad carcerem accedentes, eos devote orantes invenerunt. Rex vero Marochiorum, his auditis, furore succensus praecepit, ut sibi ducerentur. Ligatis ergo Sanctorum manibus et ipsis exspoliatis, nudis pedibus sic, plagatoribus sanguine repletis fustigando continue, ad regem sunt adducti. Quos cum vidisset rex et in fide solidissimos invenisset, introductis aliquibus mulieribus, ceteris exclusis, dixit eis: 


\section{„Convertitemini ad fidem nostram, et dabo vobis mulieres has in uxores et pecuniam magnam, et eritis honorati in regno meo."}

Beati vero martyres responderunt:

\section{„Mulieres et pecuniam tuam nolumus, sed omnia contemnimus propter Christum."}

Tunc rex ira succensus, gladium accipiens, Sanctis ab invicem separatis, uni post alium caput per medium frontis fregit. In quorum cervicibus tres gladios exemit et sic eos ferali crudelitate manu propria interfecit. Compleverunt autem suum martyrium anno Domini MCCXX, XVII. kalendas Februarii, domini Papae Honorii tertii anno IV, ferme VII annis ante mortem Sancti Francisci.

Post haec eorum corporibus et capitibus a mulieribus illis forinsecus proiectis, nequissimi populi funes pedibus et brachiis ligantes extra muros civitatis traxerunt et ibi capita proiiciebant et membra alia, per gyrum civitatis currentes et ululatum maximum facientes; et nocte vergente sacra corpora dilacerata et dispersa in campis dimiserunt. Cum vero Christiani alii elevatis manibus in coelum Dominum pro eorum triumphali martyrio collaudarent, alii eorum reliquias latenter colligerent, Saraceni innumerabiles iracundia pleni tantam lapidum multitudinem in eos iactaverunt, ut tempestas grandinis videretur. Tum Sanctorum meritis Christiani omnes fugientes illaesi ad propria redierunt, et sic timore mortis in propriis domibus clausi per triduum latuerunt. Nam illo tempore Petrus Fernandi et Martinus Alphonsi, scutiferi domini infantis, in foro per Saracenos fuerunt interfecti. Postmodum facto magno igne in campo, corpora sanctorum fratrum in illum fuerunt proiecta, ut totaliter cremarentur; sed ignis divina virtute a sanctis reliquiis tanquam a materia contraria declinabat et totaliter exstinguebatur, immo caput unius martyrum frequenter fuit in ignem proiectum et tamen saltem in capillis nullum signum combustionis apparuit et adhuc cum pelle et capillis in monasterio sanctae Crucis de Colimbria ostenditur incorruptum. Saraceni autem qutidam propter amicitiam, quidam propter lucrum, necnon Christiani ibidem captivati Sanctorum reliquias colligentes, domino Infanti obtulerunt. Qui cum magna devotione eas recipiens, ipsas commisit Iohanni Roberti canonico sanctae Crucis de Colimbria, viro perfecto, et tribus aliis innocentibus domicellis. Nullus autem audebat intrare locum, ubi sacrae reliquiae servabantur, quem alicuius facinoris vel sola conscientia arguebat. Unde illo tempore quidam miles, Petrus Rosarius nomine, habens concubinam, Rosariam nomine cum ascenderet solarium, ubi sacrae reliquiae servabantur, in medio facttus immobilis, fortiter clamavit dicens:

„Succurite, succurrite, date mihi confessionem; et facta confessione praedicto canonico et abiurata concubina, descendit liber de scala, viribus corporis recuperatis, sed ultra loqui non potuit, quousque de mandato Infantis dictus canonicus ei caput unius martyrum posuit supra pectus; et tunc loquelam et vires recuperavit, ut prius."

Quidam etiam scutifer, qui aliquando Sanctorum reliquias, quae super scutum desiccabantur, devote contrectabat, semel actui fornicario se ingessit. Et cum rediens vellet, ut prius, sacras adaptare reliquias, scutum, in quo erant, subito se levavit in altum, sic quod ipsum tangere non valebat. Poenitentia vero ductus, mox ut fuit contritus et confessus, ad locum solitum reliquiae descenderunt et se contrectari manibus eiusdem scutiferi permiserunt. Post haec dominus Infans fecit fieri duas arcas argenteas, ita quod in una erant capita cum carne desiccata, in alia vero ossa; et coram istis in capella sua quotidie orando supplicabat Sanctis, quod, ut ad terram propriam redire posset, a Domino obtinerent, cum iam contra voluntatem suam ibidem detentus longo tempore perdurasset.

Et tunc rex Miramolinus dedit sibi liberam licentiam redeundi contra suorum consilium, qui, ut cum occideret, antea consulebant. Cum vero Infans cum suis licentiatus recederet, post diem et noctem venerunt ad quendam locum, ubi prope audiebantur rugitus leonum et terribiles ululatus. Qui territi positis reliquiis, inter se et locum illum, ad quem videbant leones convenire, sacras reliquias posuerunt; 
et ex tunc nec leones viderunt nec eorum rugitus audiverunt. Cum vero viam ignorantes in quodam loco, ubi multae viae concurrebant, quam deberent eligere, dubitarent, dominus Infans praecepit, ut mula, quae martyrum deferebat reliquias, omnes equitaturas praecederet, et omnes per viam, quam eligeret, sequerentur. Mula vero, Domino dirigente, statim a via divertit, in qua Infanti erant paratae Saracenorum insidiae, ut sibi postea fuit dictum, et per quandam inusitatam et asperem incedens, per montes et valles divertebat. Et sic brutum animal per viam securiorem eos usque Septam direxit, et naves paratas Domino disponente ascendentes navigaverunt. Et prima nocte supervenientibus tenebris timebant nautae, ne in aliquos scopulos irruerent et perirent. Et tunc omnes ante reliquias prostrati sanctis martyribus supplicabant, ut eos a tanto periculo liberarent. Et ecce! Subito claritas quaedam coelitus effulsit, ita ut hinc inde mare possent conspicere navigantes.

Et tunc clare viderunt, quod ad illos scopulos naves ducebantur, sed lucis beneficio ab illis divertentes, omnibus salvis, ad desiderata littora Algisiriae et Taritae et deinde Hispalim pervenerunt; ubi supervenerunt quidam Christiani nuntiantes Infanti, quod rex Marochiorum mittebat nuntios ad eum capiendum. Quo omnes territi in Castellam, quantum potuerunt velociter gressus suos feliciter direxerunt. Et vix nautae vela levaverant, et ecce! Milites regis Marochiorum affuerunt, ut Infantem vel invitum reducerent et suos capitibus detruncarent. Sed Sanctorum meritis liberati, cum salute Hispaniam intraverunt. Cum vero Astoricam pervenissent, et hospes, in cuius domo hospitabantur, a triginta annis esset morbo paraclytico sic afflictus, ut loquela et membrorum officio privaretur, et Sanctorum tot mirabilia audivisset, prostratus ante arcam, ubi Sanctorum reliquiae servabantur, orans pro remedio sanctos fratres cum lacrimis, ibidem cuncti videntibus loquelam et omnium membrorum obtinuit sanitatem.

Dum vero appropinquaverunt Colimbriam, ubi iam fama sanctorum martyrum pervenerat, domina Orracha, regina Portugalliae supradicta, cum universo populo sacris occurrit reliquiis et cum magna devotione et solemnitate usque ad monasterium sanctae Crucis de Colimbria ipsas deducentes ibidem honorifice collocarunt. Cum autem beatus Franciscus eorum martyrium audivisset, exsultans in spiritu dixit:

„Nunc possum veraciter dicere, quod habeo quinque fratres."

Et in eodem anno, quo Sancti fuerunt interfecti, contra regem Marochiorum et eius regnum indignatio Dei in vindictam Sanctorum efferbuit. Nam manus dextra et eiusdem brachium, quibus occiderat sanctos fratres, et eiusdem partis omnia membra usque ad dextrum pedem fuerunt desiccata. In patria etiam illa de tribus annis immediate sequentibus nihil pluit; ex quo secuta est tanta sterilitas rerum et hominum pestilentia per quinque annos continuos, quod maior pars illius gentis fuit per mortalitatem deleta, ut iuxta numerum fratrum in vindictam pestilentialium annorum numerus sequeretur.

Et ut sanctorum fratrum supradictum vaticinium compleretur, regina Portugalliae Orracha praedicta post modicum tempus a sanctorum martyrum sepultura plena virtutibus ex hac vita migravit. Et eadem hora nocte profunda dominus Petrus Nuni, canonicus et sacrista, omni sanctitate praeclarus et eiusdem reginae confessor, vidit innumerabiles fratres Minores chorum intrantes; inter quos erat unus cum magna solemnitate praecedens, et post alii quinque quodam honore singulari inter alios praecellentes. Statim vero, dum chorum processionaliter intraverunt, Matutinum cum melodia indicibili cantaverunt. Dominus vero Petrus totus attonitus quaesivit ab uno eorum, ad quid et per quem locum tali hora tot fratres intraverunt, cum omnes portae monasterii essent clausae? Qui respondit:

„Nos omnes, quos hic vides, fuimus fratres Minores et nunc cum Christo gloriosi regnamus. Ille vero cum tanta pompa incedens est sanctus Franciscus, quem tantum in hac vita desiderasti videre. Alii vero quinque inter alios praecellentes sunt fratres pro Christo in Marochio interfecti, in isto rnonasterio tumulati. Et scias, quod domina Orracha regina ex hac vita migravit. Et quia ex toto corde Ordinem nostrum dilexit, Dominus Iesus Christus nos omnes huc misit, ut pro 
eius honore hic diceremus sic solemniter Malutinum; et quia tu eras eius confessor, Deus voluit, quod tu ista videres. De morte vero reginae non dubites, nam modo statim, dum recedemus, de hoc audies certa nova."

Tunc illa processio, clausis ianuis, monasterium illuc exivit. Et stalim illi de familia dictae reginae ad portam pulsaverunt et denuntiaverunt, reginam naturae debitum exsolvisse. Postea Sancti magnis coeperunt coruscare miraculis, quorum aliqua in eorum diffusiori Legenda plenius continentur. Istorum autem Sanctorum exemplo beatus Antonius, tunc canonicus in eodem monasterio sanctae Crucis, qui Fernandus Martini vocabatur, zelo martyrii flagrans Ordiuem fratrum Minorum intravit, aetatis suae anno XXV, et decem annos in Ordinc plenus sanctitate et praeclarus doctrina et miraculis in Ordine consummavit, de quibus aliqua, quae in Legenda eius maiori non ponuntur, inferius annotantur.

\section{A legenda szövegének egyezései és eltérései Pelbárt sermójától}

A források homofóniájának kutatása a sermo-irodalom elemzésének egyik fontos módszere. Ennek során a forrásszöveggel való szó szerinti egyezést aláhúzással, a tartalmilag egyező részeket pedig félkövérrel jelölik. A nem megjelölt részek összefüggéseiből rajzolódik ki a szerző saját álláspontja (cf. BÁRCZI 2007, p. 139).

\begin{tabular}{|c|c|}
\hline Chronica XXIV generalium ordinis minorum & Pelbárt \\
\hline $\begin{array}{l}\text { Eodem tempore beatus Franciscus de voluntate } \\
\text { Domini misit sex fratres perfectissimos ad } \\
\text { regnum Marochiorum, ut infidelibus costanter } \\
\text { fidem catholicam praedicarent, videlicet fratrem } \\
\text { Vitalem, Beraldum, Petrum, Adiutum, Accursium } \\
\text { et Othonem. Fratrem vero Vitalem eis dedit } \\
\text { praelatum volens, quod sibi quinque alii } \\
\text { obedirent. }\end{array}$ & $\begin{array}{l}\text { De voluntate ergo Domini beatus Franciscus misit } \\
\text { sex fratres mirae sanctitatis, vicarium fratrem } \\
\text { Vitalem, quem praefecit caeteris in praelatum, } \\
\text { fratrem Beraldum, fratrem Ottonem, fratrem } \\
\underline{\text { Accursium, fratrem Petrum, fratrem Adiutum. }}\end{array}$ \\
\hline $\begin{array}{l}\text { Cum autem fuerunt in regno Aragoniae, frater } \\
\text { Vitalis coepit graviter infirmari et videns, } \\
\text { prolongari suam infirmitatem, nolens, suo } \\
\text { corporali languore Dei negotium impediri, } \\
\text { praecepit aliis quinque praedictis fratribus, ut Dei } \\
\text { et fratris Francisci praeceptum, pergentes } \\
\text { Marochium, adimplerent. }\end{array}$ & $\begin{array}{l}\underline{\text { Cum autem venissent ad regnum Aragoniae, frater }} \\
\text { Vitalis infirmatus est graviter, quam infirmitatem } \\
\underline{\text { videns prolungari, et sic negotium impediri, ipse }} \\
\text { ibidem mansit, alii vero progressi sunt ad } \\
\underline{\text { implendam oboedientiam. }}\end{array}$ \\
\hline $\begin{array}{l}\text { Sancti vero fratres obedientes, dimisso ibi fratre } \\
\text { Vitale infirmo, Colimbriam perverunt. Domina } \\
\text { vero Orracha, regina Portugalliae, quae tunc erat } \\
\text { ibi, eos ad se vocans et cum eis de Deo loquens, } \\
\text { videns in eis tantum mundi contemptum, tantum } \\
\text { ad moriendum pro Christo voluntatis fervorem, } \\
\text { illos existimans perfectissimos Dei servos rogavit } \\
\text { eos instanter, ut a Domino orando postularent, ut }\end{array}$ & $\begin{array}{l}\text { Secundo ex divina revelatione, sicut enim Christus } \\
\text { providit et praedixit mortem sic isti. Cum enim } \\
\text { dicti fratres quinque profecti pervenissent } \\
\text { Colimbriam regina Portugalie Oracha nomine } \\
\underline{\text { videns in eis tamen mundi contemptum et tantum }} \\
\text { fervorem ad moriendum pro Christo, eos devote } \\
\begin{array}{l}\text { suscipiens rogavit instanter ut Deum orarent } \\
\text { quotenus vitae suae terminum revelaret. }\end{array}\end{array}$ \\
\hline
\end{tabular}




\begin{tabular}{|c|c|}
\hline eis suae vitae terminum revelaret. & \\
\hline $\begin{array}{l}\text { Cumque se humiliter excusarent, quod, cum } \\
\text { essent peccatores, non erant digni, quod eis } \\
\text { Dominus sua secreta revelaret, regina tam } \\
\text { efficaciter et cum multis lacrimis sanctos fratres } \\
\text { rogavit, quod se oraturos finaliter promiserunt. } \\
\text { Orantes omnes, divino illustrato oraculo, reginae } \\
\text { quae futura erant revelantes, dixerunt: „Domina, } \\
\text { non displiceat vobis quod Deus de vobis } \\
\text { misericorditer definivit. Ipse enim per nos vobis } \\
\text { denuntiat, quod post breve tempus vos ex hac vita } \\
\text { subtrahet ante dominum vestrum regem. Ipse } \\
\text { enim per nos vobis denuntiat, quod post breve } \\
\text { tempus vos ex hac vita subtrahet ante dominum } \\
\text { vestrum regem. Et hoc accelerationis mortis } \\
\text { vestrae indubitabile erit signum: sciatis enim pro } \\
\text { certo, quod nos pro Christi fide breviter } \\
\text { occidemur. De quo valde gaudemus, quia } \\
\text { Dominus nos vult in numero suorum Martyrum } \\
\text { computare. Cum autem apud Marochium } \\
\text { finiverimus dies nostros, Christiani ad istam } \\
\text { civitatem corpora nostra, ut ibi sepeliantur, } \\
\text { portabunt, et vos cum populo isto exibitis ad nos } \\
\text { recipiendum honorifice et devote. Et tunc, cum } \\
\text { ista videbitis, sciatis, quae vobis praedicimus, } \\
\text { veraciter adimplenda.” }\end{array}$ & $\begin{array}{l}\text { Qui cum dicerent se } \underline{\text { indignos }} \underline{\text { ad exposcendum }} \\
\underline{\text { divina secreta, tandem ob devotas preces et }} \\
\underline{\text { lacrimas reginae exorantibus fide firma revelatum }} \\
\underline{\text { est eis divino oraculo non solum quod postulabant, }} \\
\text { sed insuper illorum martirium complendum, et } \\
\text { eorum corpora illuc a Marochis deferenda, et ab } \\
\text { ipsa regina cum toto populo honorifice recipienda. } \\
\text { Ipsi ergo haec omnia et extremum diem reginae } \\
\text { prodixerunt et eo modo cuncta postea sunt } \\
\text { impleta. }\end{array}$ \\
\hline $\begin{array}{l}\text { Et inde sancti procedentes, Alanquerium castrum } \\
\text { devenerunt et dominae Sanciae, sorori regis } \\
\text { Portugalliae supradictae, totum suum propositum } \\
\text { revelarunt. Ipsa vero sanctissima eorum negotium } \\
\text { approbans, induit eos super habitus saecularibus } \\
\text { vestimentis, quia aliter non possent ad Saracenos } \\
\text { transire. Et sic dissimulato habitu Hispalim, } \\
\text { civitatem tunc Saracenorum, quae nunc Sibilia } \\
\text { dicitur, pervenerunt, et in hospitio cuiusdam } \\
\text { Christiani per dies octo, depositis vestimentis } \\
\text { saecularibus, latuerunt. }\end{array}$ & $\begin{array}{l}\text { Tertio ex voluntaria passione gloriosissimum } \\
\text { probatur martirium ipsorum, quoniam sicut } \\
\text { Christus voluntarie accessit ad patiendum, sic et } \\
\text { ipsi habita revelatione predicta accesserunt, et } \\
\text { cum difficultate pervenerunt ad civitatem } \\
\underline{\text { Saracenorum quae Sibilia dicitur, }}\end{array}$ \\
\hline $\begin{array}{l}\text { Quodam vero die spiritu ferventes usque ad } \\
\text { principalem mesquitam seu ipsorum oratorium } \\
\text { sine aliquo ductore venerunt. Quod cum vellent } \\
\text { intrare, Saraceni indignati eos clamoribus, } \\
\text { impulsibus ac verberibus impetentes, intrare }\end{array}$ & $\begin{array}{l}\text { et tandem spiritu ferventes usque ad principalem } \\
\text { templum ipsorum sine aliquo ductore venerunt, } \\
\text { quod cum vellent intrare, Saraceni indignati eos } \\
\text { clamoribus impulsibus et verberibus impetentes, } \\
\underline{\text { nullatenus intrare permiserunt. Haec enim est }}\end{array}$ \\
\hline
\end{tabular}


mesquitam nullatenus permiserunt. Tandem ad portam palatii accedentes, quasi ambaxiatores regi se fore missos dixerunt a Rege regum, Domino Iesu Christo. Cumque regi multa de fide catholica proposuissent, ipsum ad conversionem et suscipiendum baptismum inducendo, et multa turpia de Machometo et eius lege damnabili detexissent, rex quasi in furorem versus capitibus eos truncari iubet; tamen postea rex ad verba sui filii mitigatus iussit, eos in cuiusdam turris includi summitate.

Illi vero de turris altitudine ingredientibus et egredientibus curiam fidem Christi praedicabant, legem Maurorum et eius observatores damnantes. Quod audiens rex eos praecepit in fundo turris carceralis includi; et post, habito seniorum consilio misit eos Marochium, sicut ipsi optabant, cum domino Petro Fernardi, nobili Hispano catholico, et quibusdam aliis Christianis. Et intraverunt hospitium, in quo morabatur supradictus dominus Petrus infans; qui sanctos fratres cum magna devotione recipiens fecit eis de victualibus providere. Tunc fratres, ubicumque videbant Saracenos congregatos, eis ferventissime praedicabant. Cum vero semel frater Beraldus quendam currum ascendens populo praedicaret, contigit, quod Miramolinus rex pergens ad videndum sepulcra regum, quae sunt extra muros, inde transibat. Qui videns fratrem praedicantem miratus, ipsum fatuum existimans, praecepit, cum pro eo nollet a praedicatione desistere, ut omnes quinque fratres de civitate expellentur et quod per Christianos remitterentur ad partes fidelium sine mora. Tunc dictus dominus Petrus infans dedit eis quosdam de servitoribus suis, qui eos ducerent usque ad Septam, et inde ad partes fidelium transfretarent. Sancti vero fratres, illis in via dimissis, Marochium revertuntur et civitatem ingressi statim coeperunt Saracenis in foro existentibus praedicare. Quod rex audiens praecepit, eos in carcere recludi; ubi sine cibo et potu viginti diebus fuerunt, sola divina consolatione refecti. Postmodum accidit, quod immoderatus calor et magna intemperies aeris supervenit. Existimantes autem aliqui, quod eorum institutio ut nullis Christianorum aut sectae templum ipsorum ingredi permittant. Unde tandem accesserunt ad portam palatii et ad regem, legatos se dixerunt a rege regum Domino Iesu missos, cumque regi illi de fide catholica multa propossuisent, et de Machometo ac eius lege damnabiles falsitates detexissent, iratus rex iussit eos truncari capitibus, sed ad verba filii sui mitigatus iussit eos in summitate turris recludi.

Ipsi vero de turris altitudine Christi fidem omnibus curia egredientibus praedicabant, Machometum sectantes deceptos dicebant, et perire eternali. Tunc rex in fundo eiusdem turris illos inclusit, et postea seniorum consilio misit eos Marochium cum domino Petro qui erat Christianus, aliisque catholicorum. Dominus autem Petrus infans dictus, sectos cum magna devotione in hospitio suo recepit et necessaria eis ministravit. Iste dominus Petrus dictus est infans, quia in Hispania filii regum post primogenitum infantes appellantur; tunc fratres illi ubique videbant Saracenos eis ferventissime praedicabant, cumque frater Beraldus quendam currum in foro ascendens populo praedicaret, Miramolinus rex inde transiens ad videndum regum sepulchra quae extra muros sunt, videns fratrem praedicantem, percepit ut omnes quintos fratres de civitate expellerent, et per Christianos ad partes fidelium sine mora remitterentur. Tunc dominus Petrus infans quosdam de suis servis conductores dedit, sicque coacti sunt exire inde.

Quinto ex desiderio et iterata oblatione, nam sicut Christus obtulit se non semel adversaribus, sic et isti qui cum reducerentur, dimissis in via productoribus iterato sunt reversi Marochium, et coeperunt praedicare in foro. Unde rex eos in carcere inclusit, ubi sine cibo XX diebus fuerunt sola divina consolatione refecti, postmodum accidit immoderatus calor et maxima intemperies aeris supervenit quod extimantes propter $\underline{\text { sanctorum carcerem evenisse, rex Domini consilio }}$ 
propter carcerem sanctorum fratrum illa tempestas evenisset, rex de consilio Ababoturin, qui Christianos diligere videbatur, ipsos a carcere liberavit praecipiens Christianis, quod ad partes Christianorum eos remitterent sine mora.

Coepit tamen mirari cum aliis Saracenis, quando eos vidit corpore incolumes et mente constantes, cum tamen viginti diebus continuis fuissent in carcere sine cibo. Et cum liberi fuissent, statim voluerunt Saracenis proponere verbum Dei: sed Christiani timore regis nullatenus permiserunt, sed dederunt eis ductores, cum quibus versus partes fidelium remearent. Fratres vero, illis in via dimissis, Marochium revertuntur. Tunc habito consilio inter Christianos, dictus dominus Petrus infans eos in hospitio suo retinuit et prodire in publicum, adhibitis eis custodibus, non permisit. Post haec dominus Infans cum multis aliis Christianis et Saracenis, congregato exercitu, perrexit ad expugnandum quosdam Saracenos, qui regi nolebant obedire; et redeundo per tres dietas non potuerunt pro se vel equitaturis aquam ad bibendum alicubi invenire. Cum vero angustia sitis de vita desperarent, frater Beraldus, praevia oratione accepto brevi paxillo, fodit in terram, et statim fons erupit, de quo ad plenum biberunt homines et iumenta et utres etiam impleverunt. Et hoc facto statim fuit fons ille exsiccatus. Omnes vero, tanto miraculo viso, eos in maiori reverentia et devotione habuerunt, et multi eis habitus osculabantur et pedes.

Cum vero reversi Marochium custodiretur, ut prius, quadam feria VI. per locum quendam insuspectum de domo exeuntes se Miramolino regi eunti ad visitandum sepulcra regum audacter praesentarunt; et frater Beraldus currum ascendens coepit praesente rege intrepide praedicare. Quo rex iracundia plenus praecepit cuidam principi Saraceno, qui miraculum aquae viderat, ut eos capitali poena puniret. Tunc omnes Christiani timore mortis ad propria hospitia confugerunt, ubi firmatis ianuis latitabant; quos etiam Saraceni tenebant ab extra circumclusos. Postea dictus princeps, missis apparitoribus, eos liberavit e carcere Christianis percipiens quod ad partes Christianorum eos sine mora remitterent.

Mirabant autem omnes quod $\underline{\mathrm{XX} \text { diebus sine cibo }}$ et potu incolumes mansissent. Cum autem ducerentur ad partes fidelium fratres, $\underline{\text { illis in via }}$ dimissis Marochium redeunt. Tunc habito inter Christianos consilio dominus Petrus infans illos in suo hospitio tenuit sub custodia ne in publicum prodirent. Post haec idem dominus Petrus missus est a rege cum exercitu contra quosdam rebelles Saracenos, et duxit secum sanctos fratres. Accidit autem quod per tres dies non potuerunt pro se et equis aquam ad bibendum alicubi invenire. Desperantes idcirco de vita, frater Beraldus oratione praevia accepto brevi pasillo terram fodit et statim fons erupit, de quo ad plenum homines et $\underline{\text { iumenta totius exercitus bibentes, et utres }}$ implentes, statim hoc fecit omen, fons exsiccatus est ut clarescat, qui non nisi divino miraculo inventa est, ibi aqua. Omnes ergo percussi tanto $\underline{\text { miraculo ceperunt illos revereri et pedes eorum }}$ osculari.
Sexto gloriosum extiti eorum martirium ex crudeli occisione, sicut enim Christus crudelissime est occisus, sic et isti licet alio gente paene, tandem ei reverso exercitu illo Marochium isti fratres clam domum exeuntes praesentaverunt se regi Miramolino audacter praedicantes Christum. Ille ira plenus praecepit cuidam principi Saraceno ut illos capite truncaret. Missis ille apparitoribus iussit eos adduci alapis et ictibus percussos, tunc Christiani timore mortis ad propria hospitia confugerunt, quos adductos et in fide confessione firmos videns percepit variis tormentis torqueri. Tunc fortiter sunt flagellati, et tandem ligatis 
praecepit, eos ad se venire. Qui dum fuissent ad principis domum bis adducti, illo absente, ministri diaboli eis alapis et ictibus percutientes in maiorem carcerem recluserunt, et ibi sancti fratres Christianis et haereticis verbum Dei continue praedicabant. Tunc princeps fecit eos adduci. Quos cum invenisset constantissime fidem catholicam confitentes et iniqua Machometi et eius legis exprobrando audacter reserantes, ira magna succensus praecepit, eos variis tormentis torqueri et in diversis domibus ab invicem separatos fortiter flagellari. Tunc iniqui ministri, ligatis manibus Sanctorum et pedibus, positis funibus in collis eorum, ipsos per terram trahentes et retrahentes, sic graviter flagellarunt, quod fere viscera apparebant, super ipsorum etiam vulnera fractis vasis ferventis olei et aceti, et vasorum fragmentis super ipsorum stramentis asperis positis, Sanctos super ipsa proiicentes et volutantes; sic per totam noctem afflicti et a triginta fere Saracenis fuerant custoditi et crudeliter flagellati.

Eadem nocte fuit visum custodibus, quod lux magna de coelo descendebat et sanctos fratres recipiens ad coelos cum innumerabili multitudine sublimabat. Qui stupefacti et territi ad carcerem accedentes, eos devote orantes invenerunt. Rex vero Marochiorum, his auditis, furore succensus praecepit, ut sibi ducerentur. Ligatis ergo Sanctorum manibus et ipsis exspoliatis, nudis pedibus sic, plagatoribus sanguine repletis fustigando continue, ad regem sunt adducti. Quos cum vidisset rex et in fide solidissimos invenisset, introductis aliquibus mulieribus, ceteris exclusis, dixit eis: „Convertitemini ad fidem nostram, et dabo vobis mulieres has in uxores et pecuniam magnam, et eritis honorati in regno meo". Beati vero martyres responderunt: „Mulieres et pecuniam tuam nolumus, sed omnia contemnimus propter Christum." Tunc rex ira succensus, gladium accipiens, Sanctis ab invicem separatis, uni post alium caput per medium frontis fregit. In quorum cervicibus tres gladios exemit et sic eos ferali crudelitate manu propria interfecit. pedibus per terram huc et illuc tracti adeo sunt verberati quod fere viscera apparebant, et super ipsorum vulnera bulliens oleum et acetum fundentes super stramenta testarum volutabant, sic quoque per totam noctem a XXX Saracenis crudeliter sunt flagellati.
Eadem nocte viderunt custodes quod lux magna de caelo descendit et sanctos fratres recipiens ad coelos cum innumerabili multitudine sublimabat; quidam visione stupefacti ad carcerem accedunt et eos devote orantes inveniunt. Rex vero Marochiorum auditus istis furore succensus ut sibi ducerentur praecepit, quod expoliati ligati et fustibus continue acti ad regem ducuntur, rex autem ait eis: convertimini ad fidem nostram et dabo vobis pecuniam magnam et eritis honorati in regno meo; quibusdam etiam mulieribus introductis dixit: ,has mulieres dabo vobis in uxores”. Responderunt sancti: „omnia propter Christum contemnimus et mori pro fide parati sumus; tunc rex arrepto gladio sanctis separatis ab invicem uni post alium caput per medium frontis fregit, et tres gladios se invicem coniunctos constringens propria manu ferali crudelitate eos $\underline{\text { decollavit, et sic gloriosum compleverunt }}$ martirium". 
Postmodum facto magno igne in campo, corpora sanctorum fratrum in illum fuerunt proiecta, ut totaliter cremarentur; sed ignis divina virtute a sanctis reliquiis tanquam a materia contraria declinabat et totaliter exstinguebatur, immo caput unius martyrum frequenter fuit in ignem proiectum et tamen saltem in capillis nullum signum combustionis apparuit et adhuc cum pelle et capillis in monasterio sanctae Crucis de Colimbria ostenditur incorruptum.

Et tunc rex Miramolinus dedit sibi liberam licentiam redeundi contra suorum consilium, qui, ut cum occideret, antea consulebant. Dum vero appropinquaverunt Colimbriam, ubi iam fama sanctorum martyrum pervenerat, domina Orracha, regina Portugalliae supradicta, cum universo populo sacris occurrit reliquiis et cum magna devotione et solemnitate usque ad monasterium sanctae Crucis de Colimbria ipsas deducentes ibidem honorifice collocarunt. Cum autem beatus Franciscus eorum martyrium audivisset, exsultans in spiritu dixit: „Nunc possum veraciter dicere, quod habeo quinque fratres."

Et in eodem anno, quo Sancti fuerunt interfecti, contra regem Marochiorum et eius regnum indignatio Dei in vindictam Sanctorum efferbuit. Nam manus dextra et eiusdem brachium, quibus occiderat sanctos fratres, et eiusdem partis omnia membra usque ad dextrum pedem fuerunt desiccata. In patria etiam illa de tribus annis immediate sequentibus nihil pluit; ex quo secuta est tanta sterilitas rerum et hominum pestilentia per quinque annos continuos, quod maior pars illius gentis fuit per mortalitatem deleta, ut iuxta numerum fratrum in vindictam pestilentialium annorum numerus sequeretur.

Et ut sanctorum fratrum supradictum vaticinium compleretur, regina Portugalliae Orracha praedicta post modicum tempus a sanctorum martyrum sepultura plena virtutibus ex hac vita migravit. Et eadem hora nocte profunda dominus Petrus Nuni, canonicus et sacrista, omni sanctitate praeclarus et eiusdem reginae confessor, vidit innumerabiles fratres Minores chorum intrantes; inter quos erat unus cum magna solemnitate
Septimo ex miraculorum multorum illustratione, e quibus alique breviter narremus; cum enim corpora eorum vellent Saraceni comburere ignis extinguebat per miraculum. Item ex Christianis qui erant indignati fornicatione tangere reliquias nisi prius confiterentur non poterant, sed aut ab eis levabantur in aera, aut illi viribus totis mox destituebantur. Tandem dominus Petrus infans invocans eosdem meruit ut sibi licentia a rege daretur redeundi ad Hispaniam, et tunc illas reliquias asportavit et in via plurimis a periculis per eas est liberatus. In mari etiam nocte tenebrosa timentes pericula et istos sanctos exorantes, mox claram lucem a Deo habuerunt, et sic salvi in Hispania devenerunt; fama autem audita domina Oracha regina cum universo populo occurrit reliquiis, et solenni honore in monasterio sanctae crucis de Colimbria collocavit, et ut sancti praedixerant ad Dominum regina migravit. Eadem hora noctis quidam canonicus Petrus sacrista confessor, reginae orans in ecclesia illa vidit innumerabiles fratres minores chorum intrantes, inter quos erat unus praecedens solemnissimus, et post alii quinque qui indicibili melodia matutinum canebant. Attonitus ille quaesivit ab uno eorum unde intrassent cum fores et portae essent clausae. Qui respondent: nos sumus fratres minores qui caelo iam regnamus cum Christo. Ille praecedens est beatus Franciscus, alii quinque sunt fratres isti martires; et scito quod hac hora regina Oracha migravit quae ordinem nostrum multum dilexit. Ideo nos misit Christus Iesus ad deferendam animam eius in caelum, et sic disperuit. Et ecce nuntius advenit dicens reginam migrasse, haec sufficiant. Rogemus ergo Christum ut istorum meritibus det nobis gratiam et gloriam. Amen. 
praecedens, et post alii quinque quodam honore singulari inter alios praecellentes. Statim vero, dum chorum processionaliter intraverunt, Matutinum cum melodia indicibili cantaverunt. Dominus vero Petrus totus attonitus quaesivit ab uno eorum, ad quid et per quem locum tali hora tot fratres intraverunt, cum omnes portae monasterii essent clausae? Qui respondit „Nos omnes, quos hic vides, fuimus fratres Minores et nunc cum Christo gloriosi regnamus. Ille vero cum tanta pompa incedens est sanctus Franciscus, quem tantum in hac vita desiderasti videre. Alii vero quinque inter alios praecellentes sunt fratres pro Christo in Marochio interfecti, in isto rnonasterio tumulati. Et scias, quod domina Orracha regina ex hac vita migravit. Et quia ex toto corde Ordinem nostrum dilexit, Dominus Iesus Christus nos omnes huc misit, ut pro eius honore hic diceremus sic solemniter Matutinum; et quia tu eras eius confessor, Deus voluit, quod tu ista videres. De morte vero reginae non dubites, nam modo statim, dum recedemus, de hoc audies certa nova." Tunc illa processio, clausis ianuis, monasterium illuc exivit. Et statim illi de familia dictae reginae ad portam pulsaverunt et denuntiaverunt, reginam naturae debitum exsolvisse.

Istorum autem Sanctorum exemplo beatus Antonius, tunc canonicus in eodem monasterio sanctae Crucis, qui Fernandus Martini vocabatur, zelo martyrii flagrans Ordiuem fratrum Minorum intravit, aetatis suae anno XXV, et decem annos in Ordinc plenus sanctitate et praeclarus doctrina et miraculis in Ordine consummavit, de quibus aliqua, quae in Legenda eius maiori non ponuntur, inferius annotantur.

\section{Irodalom - References}

\section{Források}

Angelomus, Luxovensis (1565): Angelomi, Monachi ordinis D. Benedicti enarrationes in libros regum. Paulum Manutium, Aldi F., In aedibus Populi Romani, Romae.

[online] [2020. 05. 20.]

https://books.google.hu/books/about/Angelomi_monachi_ordinis_D_Benedicti_Ena.html?id=pEjG 80-v5UMC\&redir_esc=y 
AugustinUS, Hipponensis Sancti: Sermo CXXVIII. In: id. (1838): Sancti Aurelii Augustini Hipponensis Episcopi opera omnia. Post Lovaniensium theologorum recensionem. Tomus quintus, Pars altera, Bibliopolas, Parisiis, col. 2678-2683.

[online] [2019. 12. 14.]

https://books.google.hu/books?id=ae1MAQAAMAAJ

BEDA, Venerabilis (1844): Opera quae supersunt omnia. vol. IX. In: Cantica Canticorum. Cap. II. Whittaker, Londini.

[online] [2020. 01. 07.]

https://books.google.hu/books?id=GuTfAAAAMAAJ

BERNARDUS, Claraevallensis Sancti (1862): In festo omnium sanctorum. Sermo I. De lectione evangelica. In: PL 183,453-462.

[online] [2020. 01. 02.]

http://www.documentacatholicaomnia.eu/02m/1090-

1153,_Bernardus_Claraevallensis_Abbas,_Sermones_De_Sanctis._In_Festo_Omnium_Sanctorum, MLT.pdf

http://www.osmtj-osmthu.com/home/bernardus/72.html

BERNARDUS, Claraevallensis Sancti (1520): Melliflui devotique doctoris Sancti Bernardi abbatis Claraevallensis [...] opus praeclarum suos complectens sermones de tempore, de sanctis, et super cantica canticorum. Lugdunensi.

[online] [2019. 12. 16.]

https://books.google.hu/books?id=pMUPgGABQzcC

BERNARDINI, Senensis Sancti (1745): Sermo VIII. De amore miraculoso. In: id.: Opera omnia. Tomus tertius, Venetiis, pp. 176-178.

[online] [2020. 05. 17.]

https://books.google.hu/books?id=9YFKAAAAcAAJ

Biblia cum glossa ordinaria. Epistola beati Hieronimi presbiteri ad Paulinum presbite[rum] de omnibus diuin[a]e histori[a]e libris incipit ... (1481). Pars I., [Strassburg]. [online] [2020. 05.17.] https://archive.thulb.uni-jena.de/ufb/rsc/viewer/ufb derivate 00000064/Inc 83 1 00034.tif

BIVAR, F. de (1662): De veteri monachatu, et regulis monasticis libri VI. Borde \& Arnaud, Lugduni. [online] [2020. 05. 17.]

https://www.digitale-sammlungen.de/index.html?c=orte_werke\&ab=Lugduni\&l=de

https://books.google.hu/books?id=gXVCAAAAcAAJ

BONAVENTURA, Sancti (1513): De spirituali vinea sive religionis profectu, necnon de perfectiore novitiorum institutione Tractatuli duo. Joannes Stuchs, Nurenberge.

[online] [2020. 05. 17.]

https://books.google.hu/books?id=ZathAAAAcAAJ

BonaVentura, Sancti (1596): Operum. Tomus septimus, Ex Typografia Vaticana, Romae.

Busti, B. de (1503): Mariale eximii viri Bernardini de Busti ordinis Seraphici Francisci. Sermo X. De sanctitate Mariae. Norimbergae. [online] [2019. 12. 17.] https://books.google.hu/books?id=mrlQAAAAcAAJ

CASSIODORUS, F. M. A. (1589): Psalmus XXVIII. In: id.: Cassiodorus super psalmos. Venetiis, p. 40. [online] [2020.05. 17.]

https://reader.digitale-sammlungen.de/de/fss/object/display/bsb11204140_00116.html

Chronica XXIV generalium ordinis minorum (1897). Tomus III., Bonaventurea, Romae.

[online] [2019. 12. 22.] https://gallica.bnf.fr/ark:/12148/bpt6k114485d/f2.image.texteImage 
Clementine Vulgate (2005). Clementine Vulgate Project.

[online] [2020. 01. 29.] http://vulsearch.sourceforge.net/html/Sir.html

Cronica di Giordano da Giano. Cronice e alte testimonianze Francescane. Parte secunda. [online] [2019. 12. 22.]

http://www.ofs-monza.it/files/cronacadigiordanodagiano.pdf https://www.geschichtsquellen.de/repPers_119271508.html

DiONYSIUS, Carthusianus D. (1537): Dionysii Carthusiani in omnes beati Pauli Epistolas commentaria. Ioannem Roignny sub Basilico \& quatour Elemntis, Parisiis. [online] [2019. 12. 18.] https://books.google.hu/books?id=UaoJDnZM6JcC

GERSON, J. (1706): Carmen de multiplici martyrio. In: id.: Opera omnia. Ellies Dupin, Antwerpiae. [online] [2019. 12. 19.] https://books.google.hu/books?id=GBBzQsY0zewC

Glossa Ecclesiastici XXIV. In: M. MORARD (ed.): Glossae Scripturae Sacrae-electronicae (20162018), IRHT-CNRS. [online] [2020. 05. 17.]

https://gloss-e.irht.cnrs.fr/php/editions_chapitre.php?livre=../sources/editions/GLOSSliber32.xml\&chapitre $=32 \_24$

GregOrIUS, Magnus Sancti (1878a): Homiliae in evangelia 1, Homilia III. Habita ad populum in basilica Sanctae Felicitatis martyris, in die natalis eius. In: PL 76,1086-1089. [Online] [2019. 12. 13.] https://archive.org/details/patrologiaecurs 101 unkngoog/page/n548/mode/2up

http://monumenta.ch/latein/text.php?tabelle=Gregorius_Magnus\&rumpfid=Gregorius\%20Magnus, $\% 20$ Homiliae\%20in\%20Evangelia,\%201,\%20\%20\%20\%203\&level=\&domain=\&lang=0\&id=\&hil ite_id $=\&$ links $=\&$ inframe $=1$ )

GREGORIUS, Magnus Sancti (1878b): Homiliae in evangelia 2, Homilia XXVII. Habita ad populum in basilica Sancti Pancratii martyris. Lectio sancti evangelii secundum Iohannem. In: PL 76,12041210. [online] [2019. 12. 13.]

https://archive.org/details/patrologiaecurs101unkngoog/page/n608/mode/2up

GREGORIUS, Magnus Sancti (1839): Homilia S. Gregorii Papae secundi habita in basilica Sanctae Agnetis via Numentana, die natali eius. In: Breviarum Laudunense. Pars hyemalis, C. Mennesson, Lauduni, pp. 508-509.

[online] [2020. 05. 17.]

https://books.google.hu/books?id=C88-AAAAYAAJ

GREGORUS, Magnus Sancti (1705): Sancti Paterii. Liber VII, Caput VIII. In: id.: Sancti Gregorii papae opera omnia. Sumptibus Claudii Rigaud, Parisiis, col. 143-145.

[online] [2019. 12. 15.]

https://books.google.hu/books?id=wCHSM6SAyjMC

HAYMONIS, Halberstatensis (1529): Commentarium In Cantica Canticorum. In: PL 117,295-358D.

[online] [2020. 01.29.]

https://archive.org/details/patrologiaecurs04migngoog/page/n566/mode/2up

http://www.documentacatholicaomnia.eu/30_10_0840-0853-

_Haymo_Halberstatensis_Episcopus.html

http://www.documentacatholicaomnia.eu/04z/z_0840-

0853_Haymo_Halberstatensis_Episcopus_Commentarium_In_Cantica_Canticorum_MLT.pdf. $\underline{\text { html }}$

HONORIUS, Augustodunensis: Expositio in cantica canticorum. In: PL 172. 
[online] [2020. 01.08.]

http://www.documentacatholicaomnia.eu/02m/10801137,_Honorius_Augustodunensis,_Expositio_ In_Cantica_Canticorum,_MLT.pdf

HugO, de S. Victore (1526): Tertius operum M. Hugonis a S. Victore Tomus. Parisiis. [online] [2020. 04. 26.] https://books.google.hu/books?id=xyjKiNWUHbYC

KEMPIS, T.: De imitatione Christi. Lib. II., Cap. XII., De regia via Sanctae Crucis. [online] [2019. 12. 12.] http://www.disc.ua.es/ gil/de-imitatione-christi.pdf

LaSKaI, O.: Sermones de Sanctis Biga Salutis intitulati. Sermo XXX. De sancto Matthia apostolo II. [online] [2020. 01. 29.] http://sermones.elte.hu/szovegkiadasok/latinul/laskaiosvat/index.php?file $=$ os/os030

MAURUS, H.: De rerum naturis liber octavus. [online] [2020. 01. 06.] https://www.mun.ca/rabanus/drn/8.html

ORIGENIS (1844): In numeros homilia X. In: id.: Origenis opera. Tomus tertius. Paul Mellier, Parisiis, pp. 349-356. [online] [2020. 05. 17.]

https://books.google.hu/books?id=yKEHAQAAIAAJ

Patristik Bible Commentary. Glossa Ordinaria. [online] [2020. 05. 17.] https://sites.google.com/site/aquinasstudybible/home/glossa-ordinaria https://archive.thulb.uni-jena.de/ufb/rsc/viewer/ufb_derivate_00000064/Inc_83_1_00034.tif

Regula beati patris nostri Francisci (1502). Per Iacobum Britannicum Brixianum, Brixiae. [online] [2020. 05. 17.] https://books.google.hu/books?id=VFb7_w6HgtMC

Regula bullata. [online] [2019. 12. 15.] http://www.franciscanos.org/esfa/omfra.html\#regb

TAMÁs, Celanói (1996): Celanói Tamás életrajzai Szent Ferencröl. Ferences Források 2., Agapé Kiadó, Szeged - Újvidék. (ford. Balanyi Gy.)

TheOdORETI, Cyrensis (1769): Beati Theodoreti episcopi Cyri Opera omnia, ex recensione Iacobi Sirmondi. Tomi 2., Pars altera, impensis bibliopolii Orphanotrophei, Halae. [online] [2019. 12. 17.] https://books.google.hu/books?id=rTugAAAAMAAJ

Tronson, O. de (1824): Forma cleri. Ecclesiastique de Beaugé - Rusand, Paris. [online] [2020. 01. 08.] https://books.google.hu/books?id=uZMidKQMeIkC

Szakirodalom

BÁRCZI, I. (2007): Ars compilandi. Historia Litteraria 23., Universitas Kiadó, Budapest.

BERTAZZO, L. (2011): I protomartiri francescani tra storia e agiografia. In: L. BERTAZZO \& G. CASSIO (a cura di): Dai protomartiri francescani a Sant'Antonio di Padova. Atti della giornata internazionale di studi, Terni, 11 giugno 2010, Centro Studi Antoniani, Padova, pp. 31-47.

BÖRÖCZ, M. (1911): Ferencesek a középkori magyar irodalomban. Katholikus Hírlapkiadó és Nyomda Részvénytársaság, Pécs.

FODOR, P. (1997): Az apokaliptikus hagyomány és az „aranyalma” legendája. A török a 15-16. századi magyar közvéleményben. Történelmi Szemle 39 (1): 21-50.

MACEvitT, Ch. (2020): The Martyrdom of the Franciscans. Islam, the Papacy, and an Order in Conflict. University of Pennsylvania Press, Philadelphia. doi:10.9783/9780812296778 
ÖZE, S. (1991): „Büneiért bünteti Isten a magyar népet”. Egy bibliai párhuzam vizsgálata a XVI. századi nyomtatott egyházi irodalom alapján. Bibliotheca Humanitatis Historica a Museo Nationali Hungarico Digesta II., Magyar Nemzeti Múzeum, Budapest.

[online] [2020. 09. 13.]

https://adoc.pub/bibliotheca-humanitatis-historica-a-museo-nationali-hungaric.html

V. KovÁCS, S. (szerk.) (1982): Temesvári Pelbárt válogatott irásai. Európa Könyvkiadó - Magyar Helikon, Budapest.

VARGA, K. \& VÁRNAI, J. (szerk.) (2011): A ferences regula. Korai és mai értelmezések. Vita Consecrata 5., L’Harmattan Kiadó - Sapientia Szerzetesi Hittudományi Főiskola, Budapest. 